\title{
Gs/Gq signaling switch in $\beta$ cells defines incretin effectiveness in diabetes
}

\author{
Okechi S. Oduori, ${ }^{1}$ Naoya Murao, ${ }^{1}$ Kenju Shimomura, ${ }^{2}$ Harumi Takahashi, ${ }^{1}$ Quan Zhang, ${ }^{3}$ Haiqiang Dou, ${ }^{4}$ Shihomi Sakai, ${ }^{1}$ \\ Kohtaro Minami, ${ }^{1}$ Belen Chanclon, ${ }^{4}$ Claudia Guida, ${ }^{3}$ Lakshmi Kothegala, ${ }^{4}$ Johan Tolö, ${ }^{4}$ Yuko Maejima, ${ }^{2}$ Norihide Yokoi, ${ }^{1,5}$ \\ Yasuhiro Minami, ${ }^{6}$ Takashi Miki, ${ }^{1}$ Patrik Rorsman, ${ }^{3,4}$ and Susumu Seino ${ }^{1}$
}

'Division of Molecular and Metabolic Medicine, Kobe University Graduate School of Medicine, Kobe, Japan. ²Department of Bioregulation and Pharmacological Medicine, Fukushima Medical University School of Medicine, Fukushima, Japan. ${ }^{3}$ Oxford Centre for Diabetes, Endocrinology and Metabolism, Radcliffe Department of Medicine, University of Oxford, Oxford, United Kingdom. ${ }^{4}$ Metabolic Research Unit, Institute of Neuroscience and Physiology, University of Gothenburg, Gothenburg, Sweden. ${ }^{5}$ Laboratory of Animal Breeding and Genetics, Division of Applied Biosciences, Kyoto University Graduate School of Agriculture, Kyoto, Japan. 'Division of Cell Physiology, Kobe University Graduate School of Medicine, Kobe, Japan.

\begin{abstract}
By restoring glucose-regulated insulin secretion, glucagon-like peptide-1-based (GLP-1-based) therapies are becoming increasingly important in diabetes care. Normally, the incretins GLP-1 and glucose-dependent insulinotropic polypeptide (GIP) jointly maintain normal blood glucose levels by stimulation of insulin secretion in pancreatic $\beta$ cells. However, the reason why only GLP-1-based drugs are effective in improving insulin secretion after presentation of diabetes has not been resolved. ATPsensitive $\mathrm{K}^{+}\left(\mathrm{K}_{\mathrm{ATP}}\right)$ channels play a crucial role in coupling the systemic metabolic status to $\beta$ cell electrical activity for insulin secretion. Here, we have shown that persistent membrane depolarization of $\beta$ cells due to genetic ( $\beta$ cell-specific Kcnj11-/mice) or pharmacological (long-term exposure to sulfonylureas) inhibition of the $\mathrm{K}_{\mathrm{ATP}}$ channel led to a switch from Gs to $\mathrm{Gq}$ in a major amplifying pathway of insulin secretion. The switch determined the relative insulinotropic effectiveness of GLP-1 and GIP, as GLP-1 can activate both Gq and Gs, while GIP only activates Gs. The findings were corroborated in other models of persistent depolarization: a spontaneous diabetic KK-Ay mouse and nondiabetic human and mouse $\beta$ cells of pancreatic islets chronically treated with high glucose. Thus, a Gs/Gq signaling switch in $\beta$ cells exposed to chronic hyperglycemia underlies the differential insulinotropic potential of incretins in diabetes.
\end{abstract}

\section{Introduction}

Glucose homeostasis is achieved by tight regulation of insulin secretion from pancreatic $\beta$ cells in response to various physiological factors, including nutrients and hormonal and neuronal inputs. Of these factors, glucose is the primary initiator of insulin secretion $(1,2)$. Glucose-induced insulin secretion (GIIS) occurs through a sequence of precisely regulated events in pancreatic $\beta$ cells. Transport of glucose into $\beta$ cells and enhanced glucose metabolism increase the ATP/ADP ratio, thereby closing the ATP-sensitive $\mathrm{K}^{+}$ $\left(\mathrm{K}_{\text {ATP }}\right)$ channels. As $\mathrm{K}_{\text {ATP }}$ channel activity maintains a negative resting membrane potential, closure of the channels causes membrane depolarization and activates voltage-dependent $\mathrm{Ca}^{2+}$ channels (VDCCs), thereby leading to insulin granule exocytosis (3-5). The $\mathrm{K}_{\text {ATP }}$ channels thus play a crucial role in linking the $\beta$ cell's metabolic status to its electrical activity for the release of insulin (6-8).

GIIS is amplified by hormones and neurotransmitters. Many of these function by activation of the trimeric $G$ proteins $G$ s and Gq (9), which signal via cAMP and diacylglycerol (DAG)/inosi-

\section{Related Commentary: p. 6235}

Conflict of interest: The authors have declared that no conflict of interest exists. Copyright: @ 2020, American Society for Clinical Investigation.

Submitted: May 8, 2020; Accepted: September 3, 2020; Published: November 16, 2020. Reference information: J Clin Invest. 2020;130(12):6639-6655.

https://doi.org/10.1172/JCI140046. tol 1, 4, 5-trisphosphate $\left(\mathrm{IP}_{3}\right)$, respectively (10). Among them, the incretins glucagon-like peptide-1 (GLP-1) and glucose-dependent insulinotropic polypeptide (GIP), which are released by enteroendocrine L-cells and K-cells following meal ingestion, are critical for preventing postprandial hyperglycemia by amplifying insulin secretion in a glucose concentration-dependent manner (11-13). Using this glucose-dependent effect, incretin-based drugs such as dipeptidyl peptidase-4 (DPP-4) inhibitors and GLP-1 receptor agonists (GLP-1RAs) have been developed and are increasingly used worldwide for diabetes therapy. GIP and GLP-1 contribute almost equally to the incretin effect in healthy individuals (14). However, GIP-induced insulin secretion (GIPIS) is lost, while GLP-1-induced insulin secretion (GLP-1IIS) is preserved in type 2 diabetes (T2D), accounting for the unique therapeutic utility of GLP-1-based treatments (15-20). A number of studies using animal models have suggested that downregulation of the GIP receptor in $\beta$ cells explains the ineffectiveness of GIP action in insulin secretion in the diabetic state (21-24). However, downregulation of the GLP-1 receptor (GLP-1R) has also been reported in T2D, yet GLP-1 retains its insulinotropic potential $(21,23)$.

$\beta$ cell $\mathrm{K}_{\mathrm{ATP}}$ channels comprise 2 subunits: the pore-forming subunit Kir6.2 (encoded by Kcnj11), a member of the inwardly rectifying $\mathrm{K}^{+}$channel family, and the regulatory subunit sulfonylurea receptor 1 (SUR1, encoded by $A b c c 8$ ), a member of the ATP-binding cassette transporter superfamily $(8,25,26)$. Loss-of-function mutations and activating mutations of the $\beta$ cell $\mathrm{K}_{\mathrm{ATP}}$ channel are 
known to cause congenital hyperinsulinism and neonatal diabetes, respectively $(7,27,28)$. Global knockout (KO) of Kcnj11 in mice (gKcnj11 $1 /-$ mice) results in lack of GIIS both in vivo and in vitro, but these mice show only slight glucose intolerance due to increased insulin sensitivity from enhanced glucose uptake in skeletal muscles $(29,30)$. We found that GLP-1IIS from perfused pancreas was partially retained in these mice, while GIP-IIS was severely diminished. Whether or not the differential responsiveness of $\beta$ cells in gKcnj11 ${ }^{--}$mice to GLP-1 and GIP is secondary to altered paracrine effects of glucagon secreted from $\alpha$ cells and/or somatostatin secreted from $\delta$ cells due to the absence of $\mathrm{K}_{\mathrm{ATP}}$ channels in these cells could not be investigated (31).

We generated $\beta$ cell-specific Kcnj11-KO mice ( $\beta K_{c n j 11^{-/-} \text {mice) }}$ to enable clarification of the direct role of the $\beta$ cell $\mathrm{K}_{\mathrm{ATP}}$ channel in insulin secretion and glucose homeostasis. These mice exhibit severe glucose intolerance and impaired GIIS, defects that can be corrected by GLP-1, but not by GIP, indicating that the $\beta \mathrm{Kcnj}_{11}{ }^{-1}$ mouse is a useful model for studying the mechanisms underlying the differential effects of GLP-1 and GIP in insulin secretion in diabetes. In addition to studying $\beta \mathrm{Kcnj}_{111^{-/}}$mice, we examined various in vivo and ex vivo models that mimic the inactive state of $\mathrm{K}_{\text {ATP }}$ channels in $\beta$ cells. We show that persistent depolarization induces a switch from Gs to Gq signaling in $\beta$ cells in these models and that similar changes are induced in human islets by conditions emulating diabetes. We propose that this switch accounts for the clinical observation that GLP-1 but not GIP is effective in T2D.

\section{Results}

Specific deletion of the Kcnj11 gene in $\beta$ cells ( $\beta$ Kcnj11 ${ }^{-1-}$ ) severely impairs glucose tolerance and GIIS in mice. $\beta$ cell-specific Kcnj11-KO $\left(\beta \mathrm{K} \mathrm{nj11^{-/- }}\right)$ mice were generated by crossing Kcnj11 floxed mice with RIP-Cre mice (32) (Supplemental Figure 1A). Cre-negative $\left(K_{\left.c n j 11^{f / f l}\right)}\right.$ mice served as littermate controls. A 90\% reduction in Kcnj11 mRNA expression was observed in islets isolated from $\beta \mathrm{Kcnj11}^{-/-}$mice as compared with control islets, with no difference in the expression of $A b c c 8$ (SUR1), the regulatory subunit of the $\mathrm{K}_{\text {ATP }}$ channel $(8,26)$ (Supplemental Figure 1B); residual expression of Kcnj11 reflects the presence of $\mathrm{K}_{\mathrm{ATP}}$ channels in non- $\beta$ cells ( $\alpha$ and $\delta$-cells) in the islets. We compared the expression of Kcnj11 in the heart, skeletal muscles, and brain, tissues reported to express $K c n j 11$ (7), and found no difference between $\beta K c n j 11^{-/-}$and control Kcnj11 $1^{f / f l}$ mice (Supplemental Figure 1B). $\beta K_{c n j 11^{-/-}}$mice exhibited no gross abnormalities. Morphological analysis of the islets revealed $\alpha$ cells intermingled with $\beta$ cells (Supplemental Figure 1C), similar to what is observed in gKcnj11/- mice (29). Insulin content did not differ between control and $\beta \mathrm{Kcnj11}^{-/-}$islets (Supplemental Figure 1D). To confirm Kir6.2 deletion functionally, we performed whole-cell $\mathrm{K}_{\text {ATP }}$ current recordings in primary $\beta$ cells isolated from control and $\beta \mathrm{Kcnj}_{111^{-/}}$mouse islets. The measurements were performed in the standard whole-cell configuration, which involves intracellular dialysis with the medium in the recording pipette. In control cells, wash-in of ATP-free medium resulted in the development of $\mathrm{K}^{+}$conductance that could be monitored by $10 \mathrm{mV}$ hyper- or depolarizing pulses from a holding potential of $-70 \mathrm{mV}$. This current was abolished by tolbutamide, an antidiabetic sulfonylurea that inhibits $\mathrm{K}_{\mathrm{ATP}}$ channel activity. In contrast, such a tolbutamide-sensitive increase in $\mathrm{K}^{+}$currents was not detected in $\beta \mathrm{Kcnj11}^{-/} \beta$ cells when dialyzed with ATP-free medium, confirming the absence of functional $\mathrm{K}_{\text {ATP }}$ channels (Figure $1 \mathrm{~A})$. In control cells, resting $\mathrm{K}_{\mathrm{ATP}}$ conductance after washout of intracellular ATP was $3.8 \mathrm{nS} / \mathrm{pF}$, which was reduced by $90 \%$ in the presence of $100 \mu \mathrm{M}$ tolbutamide (Figure $1 \mathrm{~A}$ ). In $\beta \mathrm{Kcnj11}^{-/-} \beta$ cells, the conductance was less than $0.1 \mathrm{nS} / \mathrm{pF}$ and was not affected by tolbutamide. These differences correlated with changes in membrane potential: in control cells, the membrane potential was -70 $\mathrm{mV}$, but it was only $-25 \mathrm{mV}$ in $\mathrm{Kcnj11}^{-/-} \beta$ cells (Figure $1 \mathrm{~A}$ ).

We then characterized the phenotypic changes consequent to

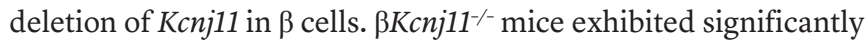
higher fasting blood glucose levels and severe glucose intolerance, as assessed by both oral and i.p. glucose challenge (Figure 1B and Supplemental Figure 1E). Whereas the increase in plasma glucose was associated with an approximately 3 -fold increase in plasma insulin in control mice, no such effect was seen in $\beta \mathrm{Kcnj11}^{-/-}$mice despite the much higher plasma glucose levels (Figure 1B). Plasma levels of total GLP-1 and GIP before and during oral glucose tolerance test (oGTT) were not affected or tended to be higher in $\beta \mathrm{Kcnj11}^{-/-}$mice than those in control mice (Figure 1C). Accordingly, the impaired insulin secretory response to glucose in $\beta \mathrm{Kcnj}_{11^{-/}}$ mice could not be attributed to reduced secretion of the incretins.

Tolbutamide $(50 \mathrm{mg} / \mathrm{kg})$ was ineffective at lowering blood glucose levels in $\beta \mathrm{Kcnj11}^{-/-}$mice (Supplemental Figure $1 \mathrm{~F}$ ). In control mice, tolbutamide $(100 \mu \mathrm{M})$ strongly but transiently stimulated insulin secretion in perfused pancreases (Supplemental Figure $1 \mathrm{G})$. In perfused pancreases of $\beta \mathrm{Kcnj11}^{-/-}$mice, basal insulin secretion (at $2.8 \mathrm{mM}$ glucose) was significantly elevated, but tolbutamide $(100 \mu \mathrm{M})$ was without stimulatory effect, consistent with the absence of functional $\mathrm{K}_{\mathrm{ATP}}$ channels in the $\beta$ cells. In fact, tolbutamide showed an inhibitory effect in $\beta \mathrm{Kcnj}_{11}{ }^{--}$, possibly reflecting the paracrine effects of tolbutamide-induced stimulation of somatostatin secretion and inhibition of glucagon secretion (33-35). Increasing the glucose concentration from 2.8 to 16.7 $\mathrm{mM}$ led to a biphasic stimulation of insulin secretion in pancreases of control mice, an effect that was greatly diminished and delayed in $\beta \mathrm{Kcnj11}^{--}$mice, while basal insulin secretion (at $2.8 \mathrm{mM}$ glucose) was significantly elevated (Figure 1D). We also determined the glucose dependence of GIIS by static incubations of isolated islets (Figure 1E). Glucose produced a concentration-dependent stimulation of insulin secretion in control islets at glucose concentrations of more than $5.6 \mathrm{mM}$. Insulin secretion from the islets of $\beta \mathrm{Kcnj11}^{-/-}$mice was significantly elevated even at $0.5 \mathrm{mM}$ glucose, and increasing glucose concentrations stimulated insulin secretion to some degree, with maximal response much lower than that of control mice (Figure 1E): a "crossover" was observed at approximately $12 \mathrm{mM}$ glucose explaining why $\beta \mathrm{Kcnj}_{11}{ }^{-/-}$mice are glucose intolerant. There was no difference in glucagon secretion between the islets isolated from $\beta \mathrm{Kcnj}_{11^{-/-}}$mice and those from control mice (Supplemental Figure $1 \mathrm{H}$ ). These results indicate that $\beta$ cell $\mathrm{K}_{\mathrm{ATP}}$ channels are essential for maintaining normal blood glucose levels, GIIS, and sulfonylurea-induced insulin secretion.

GLP-1-but not GIP-based treatment restores glucose tolerance and insulin secretion in $\beta \mathrm{Kcnj11}^{-/-}$mice. Incretin-based antidiabetic drugs such as DPP-4 inhibitors and GLP-1RAs act by amplifying insulin secretion in patients with T2D $(15,19)$. We therefore investigated whether incretin-based treatments are effective in $\beta \mathrm{Kcnj11}^{-/-}$mice. 
A
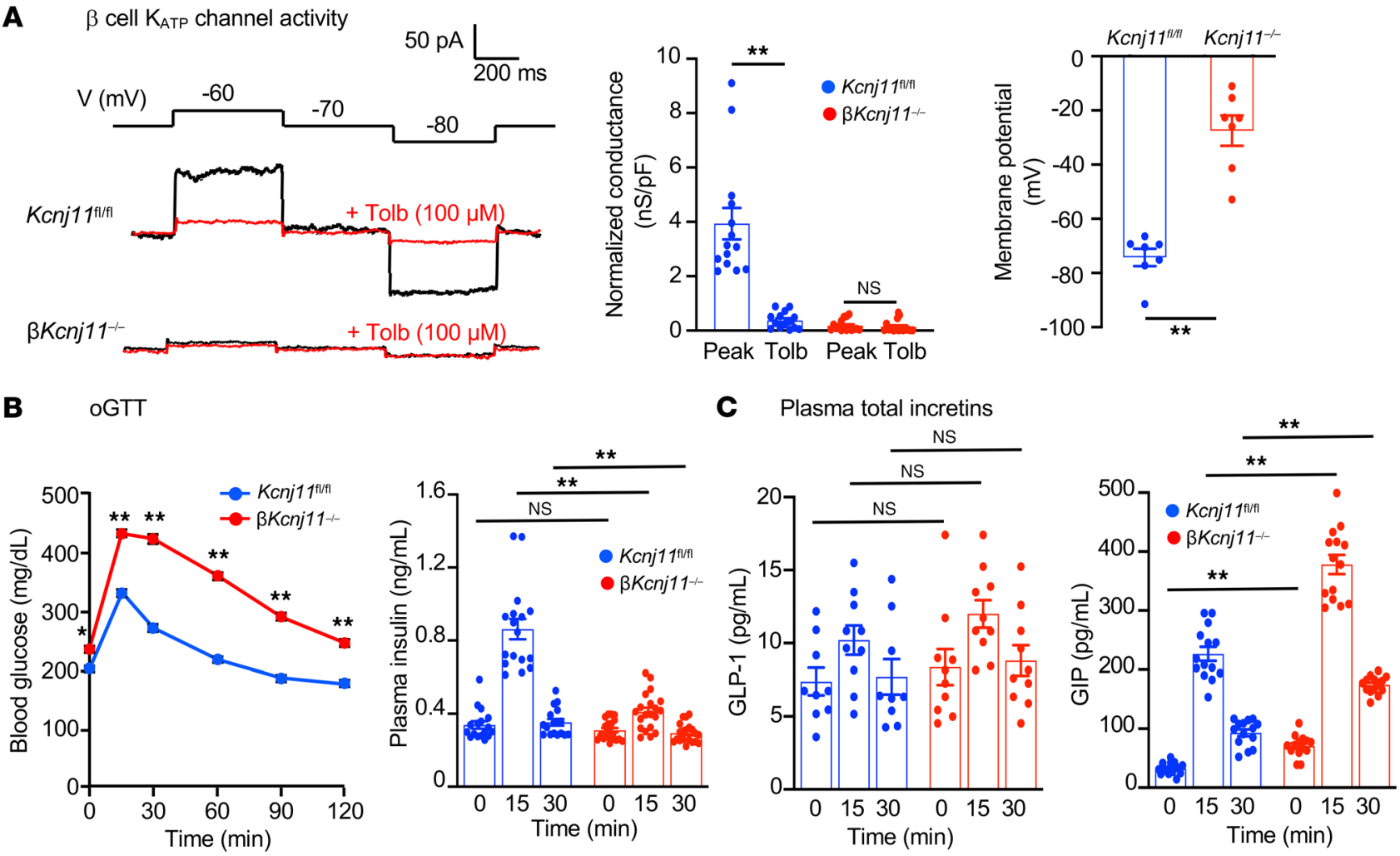

D

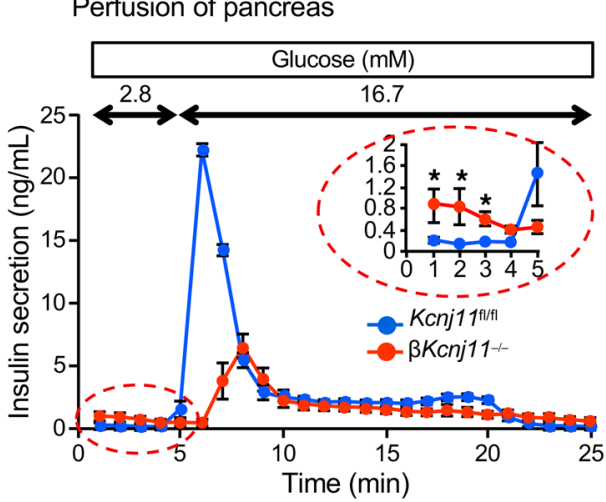

E Isolated islets

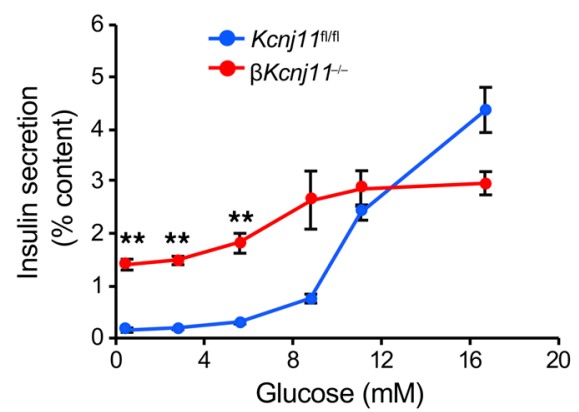

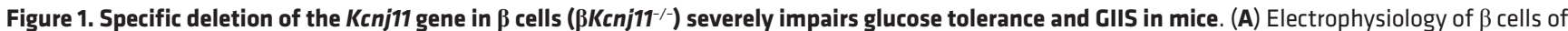
$K c n j 11^{f / f l}$ and $\beta K c n j 11^{-/-}$mice. Left: representative recordings of whole-cell $\mathrm{K}_{\text {ATP }}$ currents in primary $\beta$ cells isolated from $K c n j 11^{f / f l}$ and $\beta K c n j 11^{-/-}$mice. Middle: conductance normalized to cell capacitance ( $n=14$ for $K c n j 1^{f / / f / f} ; n=16$ for $K c n j 11^{f / f f l}$ mice). Right: resting membrane potential of primary $\beta$ cells from control and $\beta K c n j 11^{-/-}$mice measured by perforated patch $(n=7)$. (B) oGTT and corresponding plasma insulin levels. Left: blood glucose $(n=12)$. Right: plasma insulin ( $n=17-20$ for each point). (C) Plasma levels of total incretins in $K c n j 11^{f / f f}$ and $\beta K c n j 11^{-/-}$mice. Glucose $(1.5 \mathrm{~g} / \mathrm{kg})$ was administered to conscious mice fasted for 6 hours ( $n=9-14$ for each point). (D) Insulin secretion from perfused mouse pancreases. Mice were fasted overnight before perfusion experiments commenced $(n=4)$. (E) Dose-dependent effects of glucose on insulin secretion from the islets of $K c n j 11^{f / f / f l}$ and $\beta K c n j 11^{-/-}$mice. Islets were preincubated for 30 minutes in KRBB containing $2.8 \mathrm{mM}$ glucose and then stimulated with concentrations of glucose as indicated $(0.5,2.8,5.6,8.8,11.1$, and $16.7 \mathrm{mM})$ for 30 minutes ( $n=6-8$ for each point). A representative result of 3 independent experiments is shown. Statistical analyses were performed by 2 -tailed Student's unpaired $t$ test (A) or 2-way ANOVA by followed by Dunnett's post hoc test (B-E). Data are represented as mean \pm SEM. ${ }^{*} P<0.05$; ${ }^{* *} P<0.01$.

The DPP-4 inhibitor sitagliptin $(2 \mathrm{mg} / \mathrm{kg})$ restored fasting normoglycemia and glucose tolerance in $\beta K_{c n j 11^{-/}}$mice (Figure $2 \mathrm{~A}$ and Supplemental Figure 2A). Sitagliptin increased plasma levels of active GLP-1 as well as GIP in $\beta K c n j 11^{-/-}$mice beyond what was observed in control mice (Figure 2B), and improved the glucoseinduced increase in plasma insulin (Figure 2C). To determine the relative contribution of each incretin, we used the GLP-1 receptor (GLP-1R) antagonist exendin-9 to block the GLP-1R-mediated component. Exendin-9 $(50 \mu \mathrm{g} / \mathrm{kg})$ abolished the effects of sitagliptin on glucose tolerance and insulin secretion in $\beta \mathrm{Kcnj} 11^{-/}$mice (Figure 2D and Supplemental Figure 2B), indicating that the effect of sitagliptin is due to increased GLP-1 levels. The findings that the GLP-1RA liraglutide ( $50 \mu \mathrm{g} / \mathrm{kg}$ ) improved glucose tolerance as well as fasting blood glucose levels and increased insulin secretion in $\beta K_{c n j 11^{-/}}$mice corroborate this conclusion (Figure $2 \mathrm{E}$ and Supplemental Figure 2C). Injection i.p. of GLP-1 $(100 \mu \mathrm{g} / \mathrm{kg})$ reduced 
A OGTT

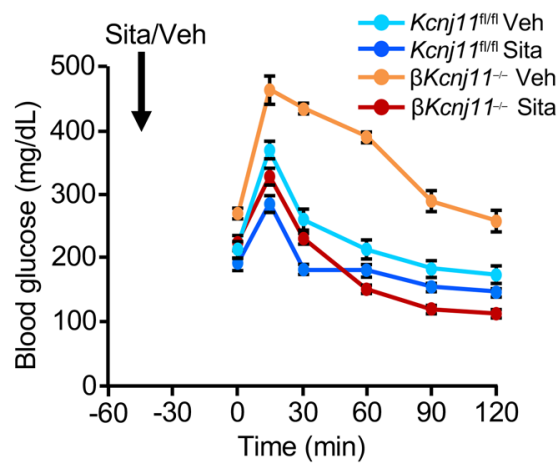

C Plasma insulin

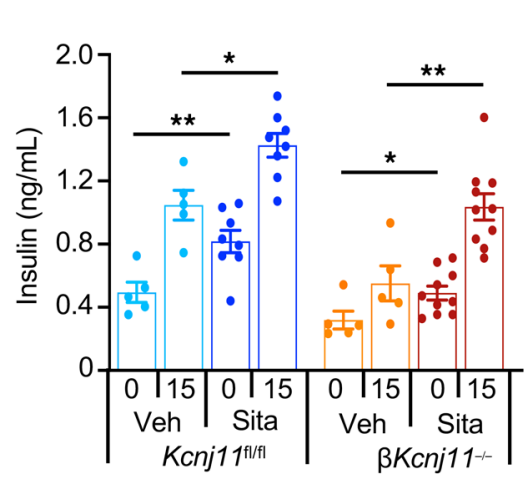

E OGTT

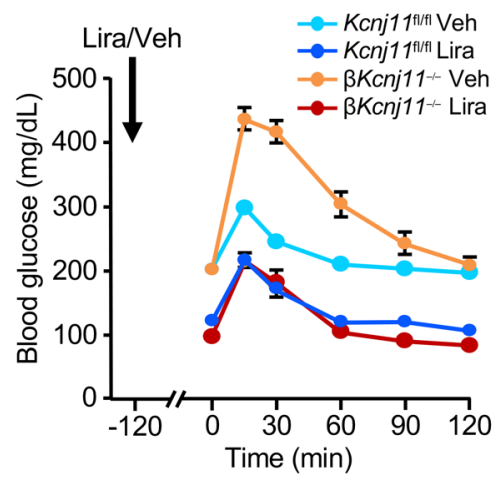

B Plasma active incretins
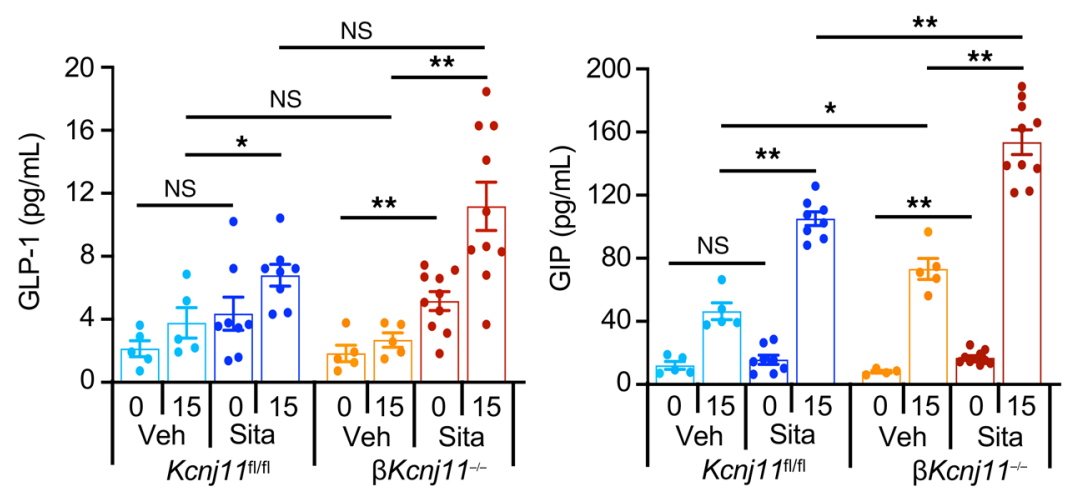

D OGTT
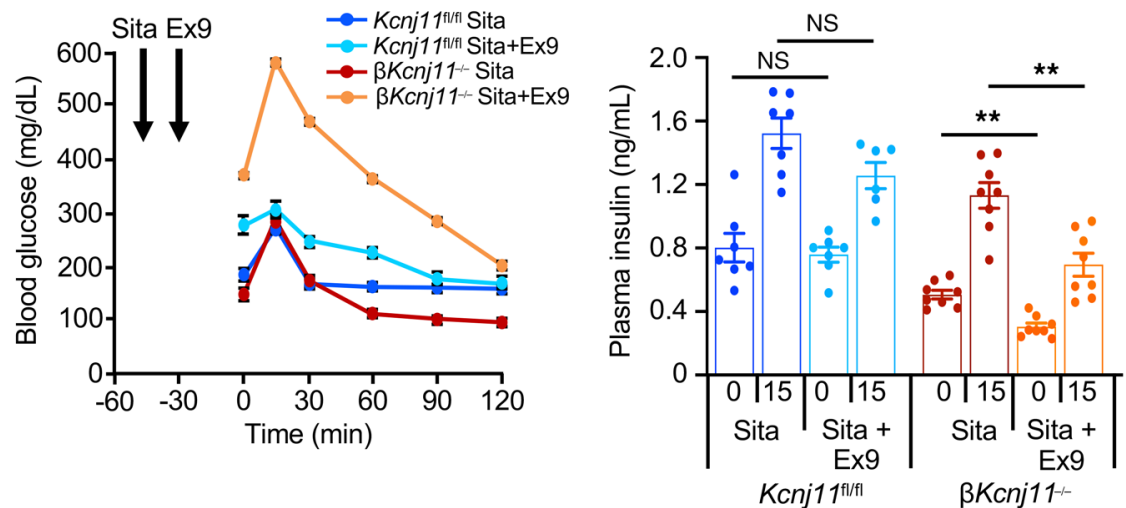

F Perfusion of pancreas
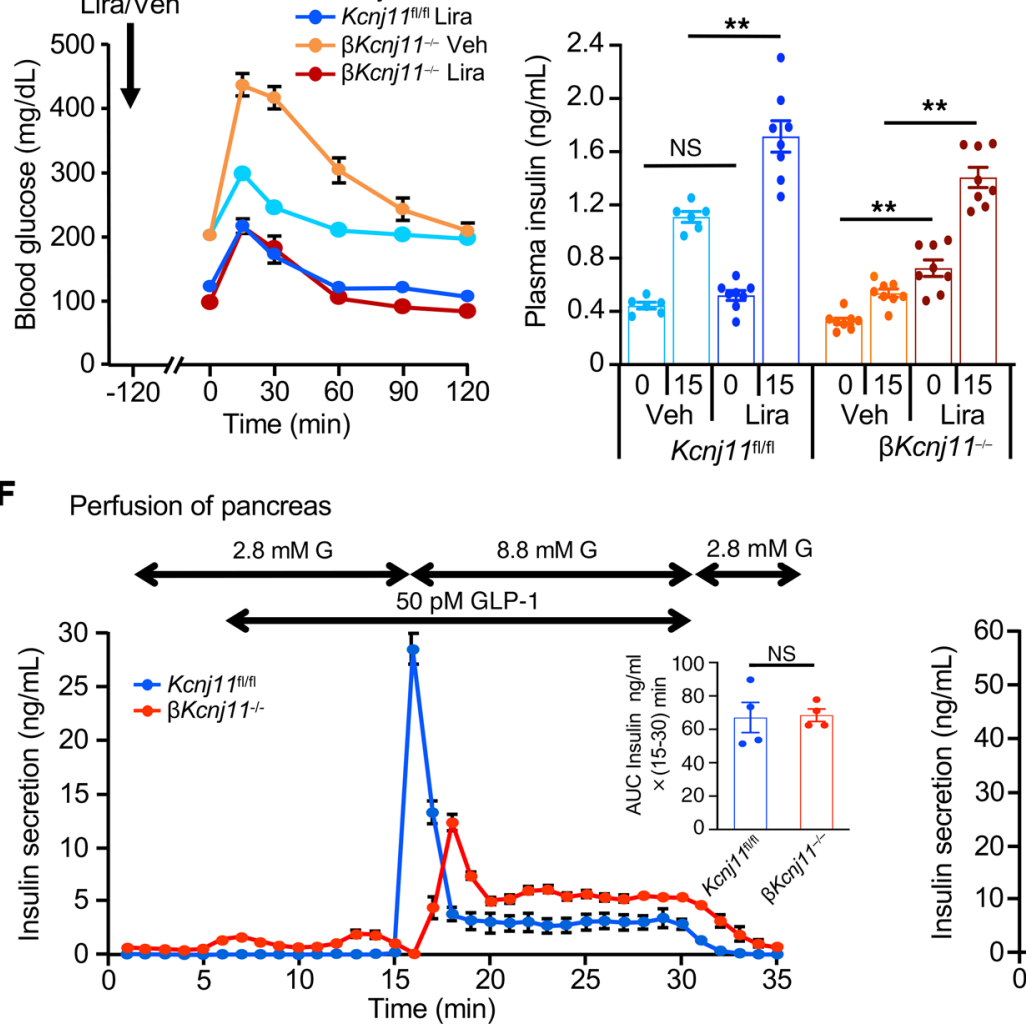

G Isolated islets
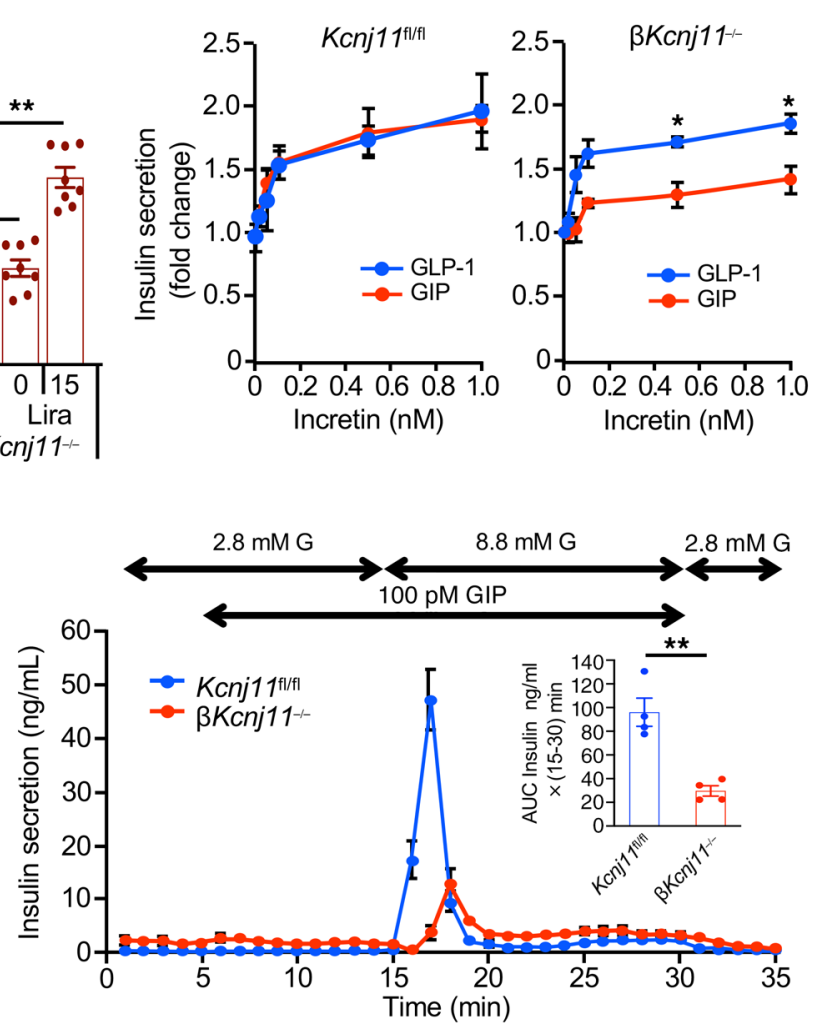
Figure 2. GLP-1- but not GIP-based treatment restores glucose tolerance

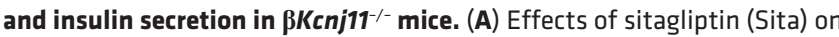
oGTT. Sita ( $2 \mathrm{mg} / \mathrm{kg}$ ) was orally administered to mice 45 minutes before glucose challenge $(1.5 \mathrm{~g} / \mathrm{kg}$ ) ( $n=5-8$ mice per group). Veh, vehicle (water). (B) Plasma active incretins before and 15 minutes after glucose challenge shown in $\mathbf{A}$ ( $n=5-10$ for each point). (C) Plasma insulin before and 15 minutes after glucose challenge shown in $\mathbf{A}$ ( $n=5-10$ for each point). (D) Effects of exendin-9 (Ex9) on blood glucose and plasma insulin during oCTT following sitagliptin treatment. Sitagliptin (orally) and exendin-9 (50 $\mu \mathrm{g} / \mathrm{kg}$, i.p.) were administered 45 minutes and 15 minutes, respectively, before glucose challenge ( $n=6-10$ per group for blood glucose; $n=7-8$ for each point for plasma insulin). Vehicle, water. (E) Effects of liraglutide (Lira) on blood glucose and plasma insulin. Liraglutide ( $50 \mu \mathrm{g} / \mathrm{kg}$, i.p.) was administered to mice 120 minutes before glucose challenge ( $n=7-12$ per group for blood glucose; $n=6-8$ for each point for insulin). Vehicle, saline. (F) Effects of incretins on insulin secretion from perfused pancreases. Total amount of GLP-1IIS or GIPIIS over a period of 15-30 minutes is expressed as AUC, in insert ( $n=4$ for both groups). (G) Dose-dependent effects of incretins on insulin secretion from pancreatic islets. Amplifying effects of each incretin at the indicated concentrations $(0,0.05,0.1,0.5$, and $1 \mathrm{nM})$ ( $n=6-8$ for each point). Statistical analyses were performed by 2-way ANOVA followed by Dunnett's post hoc test (A-D, G) or by 2-tailed Student's unpaired $t$ test $(\mathbf{F})$. Data are represented as mean \pm SEM. ${ }^{*} P<0.05$; ${ }^{*} P<0.01$.

fasting blood glucose levels and glucose excursion in $\beta \mathrm{Kcnj11^{-1 }}$ mice to levels of control mice during i.p. glucose tolerance test (i.p.GTT) (Supplemental Figure 2D). The finding that this effect was observed during an i.p.GTT enables us to rule out the influence of endogenous incretins, as they would be released only during an oGTT. In contrast, the glucose-lowering effect of GIP $(100 \mu \mathrm{g} /$ $\mathrm{kg}$ ) during i.p.GTT was markedly diminished in $\beta \mathrm{Kcnj} 11^{-/-}$mice (Supplemental Figure 2E).

To directly evaluate the distinct insulinotropic potentials of GLP-1 and GIP in $\beta K_{c n j 11^{-/}}$mice, we measured insulin secretion ex vivo using the perfused pancreas technique (Figure $2 \mathrm{~F}$ ). Although the amplification of first-phase insulin secretion by GLP-1 was reduced in $\beta K_{c n j 11^{-/}}$mice, second-phase was significantly enhanced, such that the total amount of insulin secretion in response to GLP-1 was similar in control and $\beta \mathrm{Kcnj11}^{-/-}$mice (Figure 2F and Supplemental Figure 2). When the experiment was repeated with GIP, the AUC was reduced by approximately $75 \%$ (Figure 2F). In addition, we performed perfusion experiments of pancreases from $\beta \mathrm{Kcnj11}^{-/-}$mice using a 100-fold increase in GIP concentration $(10 \mathrm{nM})$ in the presence of $16.7 \mathrm{mM}$ glucose (Supplemental Figure 2). There was no significant increase in GIPIIS from pancreases of $\beta \mathrm{Kcnj11}^{--}$mice compared with that shown in Figure $2 \mathrm{~F}$, indicating that the GIP-amplifying effect on insulin secretion is virtually abolished in $\beta$ cells of $\beta \mathrm{Kcnj}_{\mathrm{c}}{ }^{-/}$mice.

We also compared the dose dependence of GLP-1's and GIP's amplifying effects on GIIS using isolated islets. Whereas the amplifying effect of GLP-1 was comparable in control and

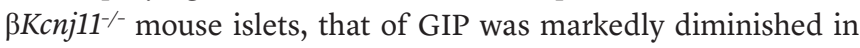
$\beta K c n j 11^{-\frown}$ mouse islets at all concentrations examined (Figure 2G). For both agonists, stimulation was nearly maximal at concentrations as low as $100 \mathrm{pM}$.

Gs to Gq signaling switch in Kcnj11- $\beta$ cells accounts for effectiveness of GLP-1RAs and Gq-specific agonists in amplification of insulin secretion. While GLP-1 amplifies GIIS by mechanisms that involve both Gs and Gq $(11,36)$, GIP does so only by the Gs- mediated mechanism $(11,37)$. We examined the expressions of Gipr, Glp1r, adenylyl cyclases (Adcys), and phosphodiestrases (Pdes) in $\beta \mathrm{Kcnj11}^{-/-}$islets and control islets, but detected no differences (Supplemental Figure 3, A-C). The adenylyl cyclase inhibitor MDL-12330A $(10 \mu \mathrm{M})$ abolished the amplifying effects of both GLP-1 and GIP on GIIS in control islets (Figure 3A). In $\beta K c n j 11^{-/}$islets, MDL-12330A abolished the amplifying effect of GIP, but only moderately reduced the response to GLP-1 (Figure $3 A)$. These results indicate that while the effects of both GLP-1 and GIP are mediated almost exclusively by Gs signaling in the $\beta$ cells of control mice, the stimulatory effect by GLP- 1 is principally independent of Gs signaling in $\beta \mathrm{Kcnj}_{\mathrm{c}} 1^{-/}$mice. GLP-1R was originally reported to couple to Gs (38), but was later found to also couple to $\mathrm{Gq}$ in reconstituted systems $(39,40)$ and in $\beta$ cells when used at physiological (pM) concentrations (41). We therefore explored the possible involvement of $\mathrm{Gq}$ signaling in the amplifying effect of GLP-1 on insulin secretion in $\beta$ Kcnj11-- mice using YM-254890 $(100 \mathrm{nM})$, an inhibitor of $\mathrm{Gq}(42)$. Whereas the amplification of GIIS by carbachol, an acetylcholine analog that signals via Gq (43), was abolished by YM-254890 in both control and $\beta \mathrm{Kcnj11}^{--}$mouse islets (Figure 3B), that of GIP was unaffected by the inhibitor in both control and $\beta K_{c n j 11}-$ islets. Intriguingly, the amplifying effect of GLP-1 was not altered by YM-254890 in control islets, but was abolished in $\beta \mathrm{Kcnj11}^{-/}$islets (Figure $3 \mathrm{~B}$ ), suggesting a switch from Gs to Gq signaling. It is noteworthy that not only was the effect of GLP-1 eliminated by YM-254890 in $\beta K c n j 11^{-/-}$islets, the increase in basal insulin secretion (at $2.8 \mathrm{mM}$ glucose) was also significantly reduced by the compound (Figure $3 \mathrm{C}$ ), raising the possibility that the elevation of basal insulin secretion also reflects the enhanced $\mathrm{Gq}$ signaling. Likewise, the insulinotropic effects of palmitate and the GPR40 agonist MK-2305 $(1 \mu \mathrm{M})(44)$, the actions of which are in part or wholly mediated through Gq signaling, were enhanced in $\beta$ cells of $\beta \mathrm{Kcnj11}^{-/-}$mice (Figure 3D).

To facilitate the study of Gq signaling in $\mathrm{K}_{\mathrm{ATP}}$ channel-deficient $\beta$ cells, we generated Kcnj11-knockout $\beta$ cell lines (Kcnj11 ${ }^{-/-}$ $\beta C L 1$ and Kcnj11 $1^{--} \beta C L 2$; Supplemental Figure 3D) from parental MIN6-K8 (Kcnj11 ${ }^{+/} \beta C L$, hereinafter referred to as parental control) by the CRISPR/Cas9 system (45). The successful knockout of functional $\mathrm{K}_{\mathrm{ATP}}$ channels in Kcnj11 $/-\beta C L 1$ and -2 was confirmed by electrophysiology (Supplemental Figure 3E) and sulfonylureainduced insulin secretion (Supplemental Figure 3F); there was no resting conductance sensitive to tolbutamide or diazoxide. Both cell lines should therefore be suitable for studying intracellular signals in $\mathrm{K}_{\mathrm{ATP}}$ channel-deficient $\beta$ cells: Kcnj11 ${ }^{-/} \beta$ CL1 was chosen for further studies. Insulin secretory responses to incretins in Kcnj11 ${ }^{-/} \beta C L 1$ were similar to those in the islets of $\beta \mathrm{Kcnj11}^{-/}$mice (Supplemental Figure 3G). cAMP production by GLP-1 in Kcnj11-/$\beta C L 1$ was decreased significantly compared with that in parental control (Supplemental Figure 3H), indicating that Gs signaling is reduced in $\mathrm{K}_{\mathrm{ATP}}$ channel-deficient $\beta$ cells.

Activation of $\mathrm{Gq}$ signaling promotes insulin secretion mainly through 2 pathways: the DAG/PKC pathway and the $\mathrm{IP}_{3} / \mathrm{Ca}^{2+}$ pathway $(46,47)$. We monitored PKC activity using phosphoserine PKC substrate antibody (48). Antibody reactivity to a number of proteins was increased in Kcnj11-- $\beta C L 1$ compared with parental control cells under basal conditions (Figure 3E), indicating that the DAG/PKC pathway is enhanced in Kcnj11 ${ }^{-/} \beta$ CL1. To deter- 
A Effects of adenylyl cyclase inhibitor

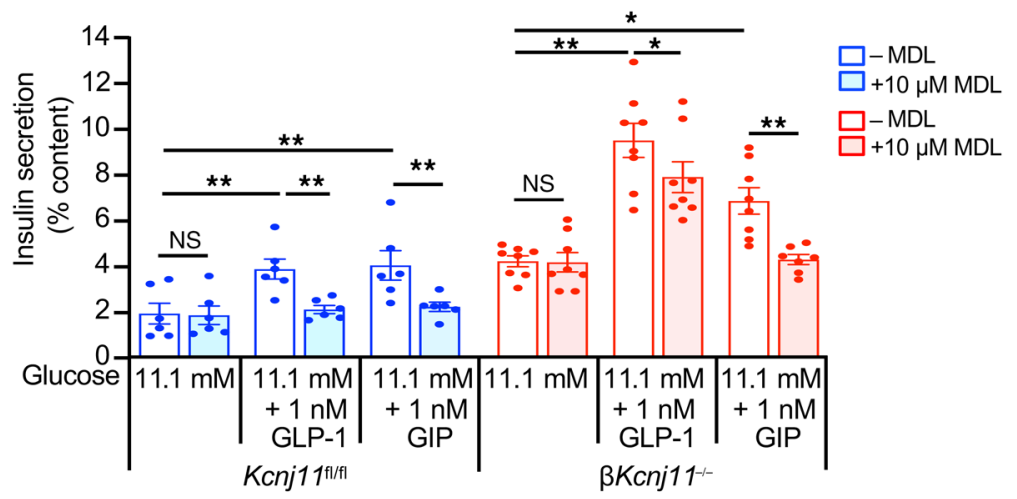

C Effects of $\mathrm{Gq}$ inhibitor

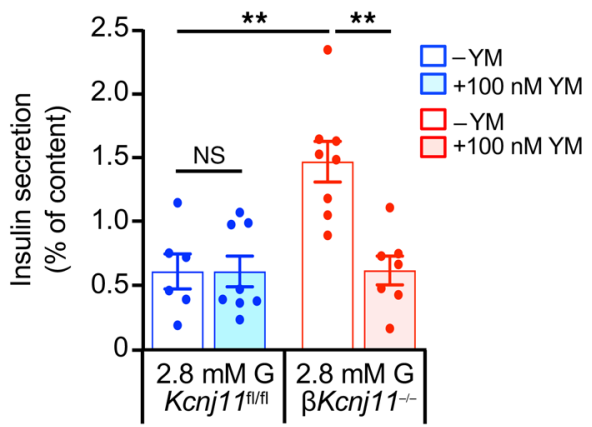

B Effects of $\mathrm{Gq}$ inhibitor

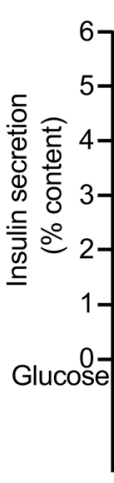

$\stackrel{N S}{-}$<smiles>C1CCCCC1</smiles>
$\frac{\pi \star}{=}=\frac{\pi}{=}$ $\stackrel{\star \star}{\longleftarrow}$
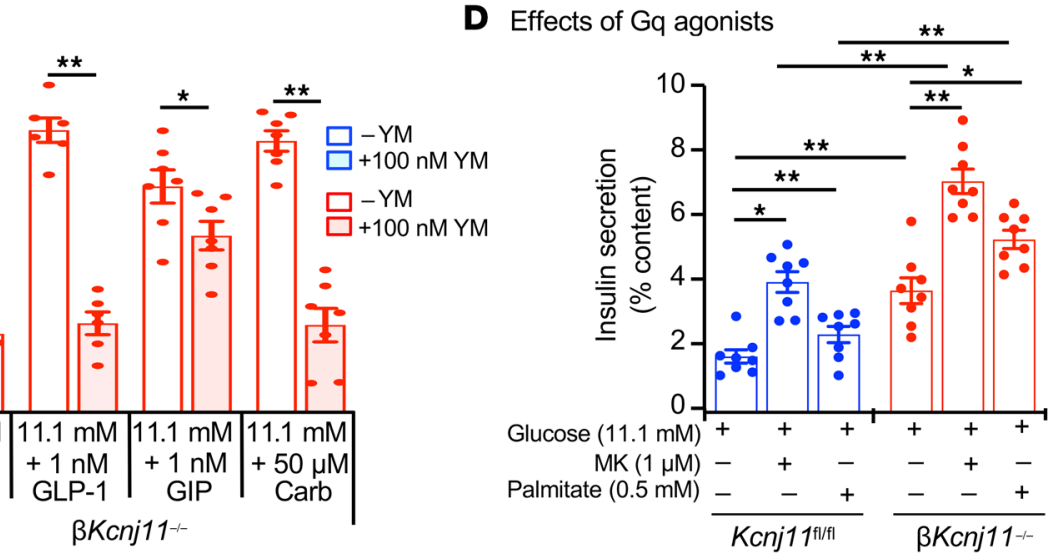

E PKC activity

F IP1

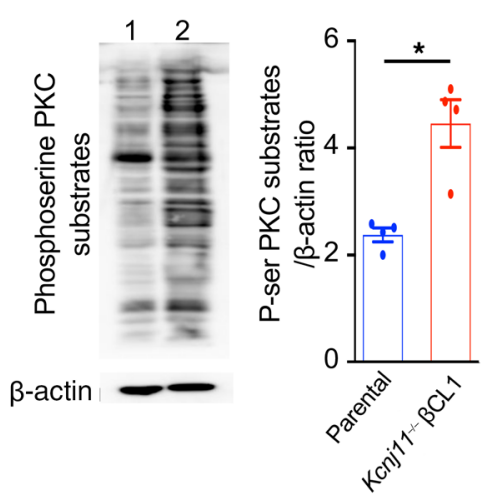

G Intracellular calcium
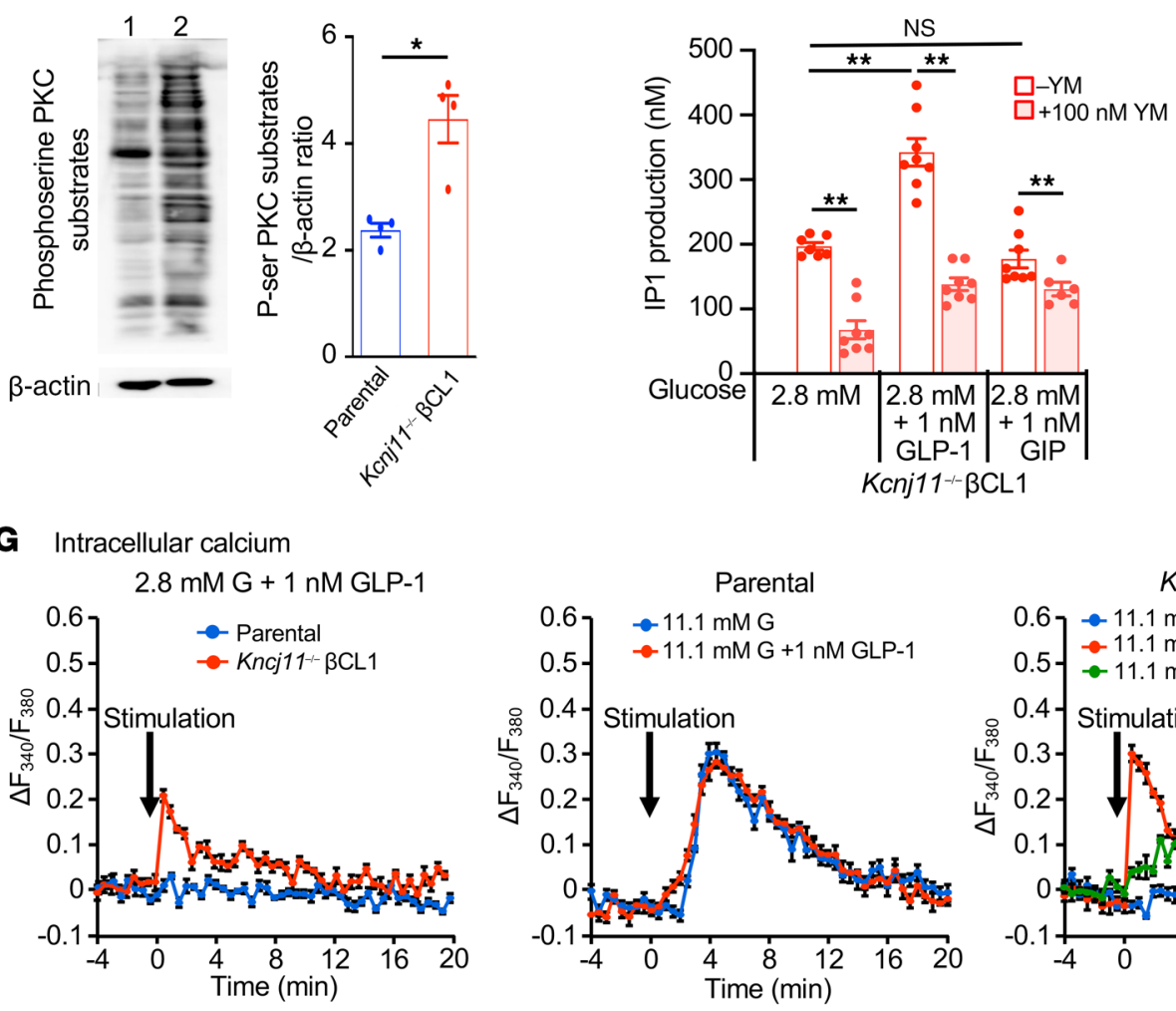

Kcnj11-i- $\beta$ CL1

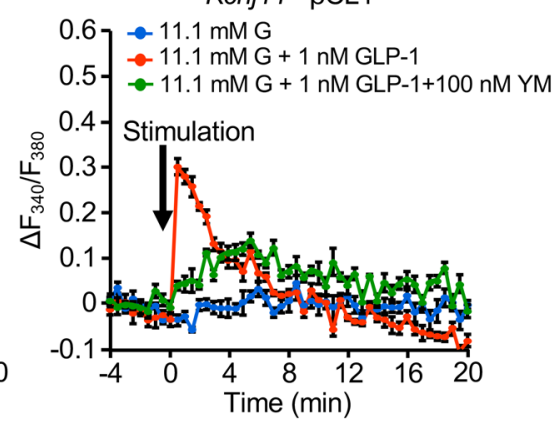


Figure 3. Gs to Gq switch in $K c n j 11^{-1-} \beta$ cells accounts for GLP-1 effectiveness in amplification of insulin secretion. (A) Effects of MDL-12330A (MDL) on GLP-1IIS and GIPIIS from islets ( $n=6-8$ for each condition). Similar results were obtained in 2 independent experiments. (B) Effects of YM-254890 (YM) on GLP-1IIS and GIPIIS from islets ( $n=6-8$ for each condition). Similar results were obtained in 4 independent experiments. Carb, carbachol. (C) Effects of YM-254890 on basal insulin secretion from islets $(n=6-8)$. (D) Effects of $\mathrm{Gq}$ agonists on insulin secretion from islets ( $n=8$ for each condition). Similar results were obtained in 4 independent experiments. MK, MK-2305. (E) Western blot analysis of phosphoserine PKC substrates in $\beta$ cell lines. Left: representative blot: lane 1, parental control; lane 2, $\mathrm{Kcnj11^{-/- }} \beta \mathrm{CL} 1$. Right: densitometric analysis of the relative abundance of phosphoserine PKC substrates ( $n=4$ for each). Whole cell lysates incubated with $2.8 \mathrm{mM}$ glucose were used. (F) IP1 in Kcnj11/- $\beta C L 1$ $(n=7-8)$. Similar results were obtained in 2 independent experiments. Note that IP1 in parental control was not detected in any condition indicated. (C) Intracellular $\mathrm{Ca}^{2+}\left(\left[\mathrm{Ca}^{2+}\right]_{i}\right)$. Left: effects of GLP-1 on $\left[\mathrm{Ca}^{2+}\right]_{i}$ at $2.8 \mathrm{mM}$ glucose. Middle: effects of high (11.1 mM) glucose alone and high glucose plus GLP-1 on $\left[\mathrm{Ca}^{2+}\right]_{i}$ in parental control. Right: effects of high glucose alone, high glucose plus GLP-1, and high glucose plus GLP-1 plus YM-254890 in Kcnj11 ${ }^{-1-} \beta C L 1$. Increment of $\left[\mathrm{Ca}^{2+}\right]_{i}$ above basal level at 2.8 $\mathrm{mM}$ glucose ( $\triangle \mathrm{F} 340 / \mathrm{F} 380)$ is shown ( $n=6$ for each). Statistical analyses were performed by 2-way ANOVA followed by post hoc Tukey's test (A, D, and $\mathbf{F}$ ) or Dunnett's test (C) and by 2-tailed Student's unpaired $t$ test (B and $\mathbf{E})$. Data are represented as mean \pm SEM. ${ }^{*} P<0.05:{ }^{* *} P<0.01$.

mine whether the DAG/PKC pathway is also involved in GLP-1stimulated conditions, we examined the effect of GLP-1 on PKC activity. Overall PKC activity was increased by both GLP-1 and carbachol in parental control. In contrast, overall PKC activity

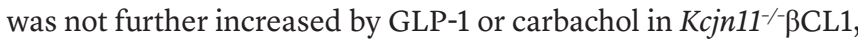
compared with that at basal state (Supplemental Figure 3I). However, the possibility that some substrates for PKC involved in the GLP-1 amplifying effect are activated cannot be ruled out. We also assessed the $\mathrm{IP}_{3} / \mathrm{Ca}^{2+}$ pathway. For evaluation of the pathway, inositol monophosphate (IP1) content was measured rather than IP because it is a more stable downstream metabolite of $\mathrm{IP}_{3}$. While IP1 was undetectable in parental control cells under basal conditions or following GLP-1 stimulation, it was markedly increased in Kcnj11 ${ }^{-/} \beta C L 1$ at both 2.8 and $11.1 \mathrm{mM}$ glucose, an effect enhanced further by GLP-1,but not by GIP (Figure 3F). These changes were antagonized by YM-254890.

We then correlated these effects to changes in cytoplasmic $\mathrm{Ca}^{2+}\left(\left[\mathrm{Ca}^{2+}\right]_{\mathrm{i}}\right)$. Basal $\left[\mathrm{Ca}^{2+}\right]_{\mathrm{i}}$ measured at $2.8 \mathrm{mM}$ glucose in $\mathrm{Kcnj11}^{-1-}$ $\beta C L 1$ was significantly higher than that in parental control (Supplemental Figure 3J), as expected for cells depolarized due to the deactivation of the $\mathrm{K}_{\text {ATP }}$ channels. At low $2.8 \mathrm{mM}$ glucose, GLP-1 did not increase $\left[\mathrm{Ca}^{2+}\right]_{\mathrm{i}}$ in parental control,whereas it significantly increased $\left[\mathrm{Ca}^{2+}\right]_{\mathrm{i}}$ in $\mathrm{Kcnj11}^{-/-} \beta \mathrm{CL} 1$ (Figure $3 \mathrm{G}$ ). High glucose (11.1 $\mathrm{mM})$ increased $\left(\left[\mathrm{Ca}^{2+}\right]_{\mathrm{i}}\right)$ in parental control, but addition of GLP-1 did not increase $\left[\mathrm{Ca}^{2+}\right]_{\mathrm{i}}$ any further (Figure $3 \mathrm{G}$ ). In contrast, $\mathrm{Kcnj11^{-/- }}$ $\beta C L 1$ did not respond to $11.1 \mathrm{mM}$ glucose, but addition of GLP-1 elicited a large $\left[\mathrm{Ca}^{2+}\right]_{\mathrm{i}}$ transient, which was markedly diminished by 100 nM YM-254890 (Figure 3G).

Collectively, these results indicate that the amplifying pathway in insulin secretion is switched from $\mathrm{Gs}$ to $\mathrm{Gq}$ signaling in $\mathrm{K}_{\mathrm{ATP}}$ channel-deficient $\beta$ cells. We also performed whole-islet RNA-Seq, but found no difference in the expressions of $G$ protein signalingrelated genes, calcium signaling-related genes, and insulin exocytosis-related genes between $\beta K c n j 11^{f / f l}$ and $\beta K c n j 11^{-/}$islets (Sup- plemental Table 1). Moreover, since there were no differences in endogenous $\mathrm{G} \alpha \mathrm{s}$ and $\mathrm{G} \alpha \mathrm{q}$ protein levels between parental control and $\mathrm{Ccnj11}^{-/-} \beta \mathrm{CL} 1$ (Supplemental Figure 3K), the signaling switch in $\mathrm{Kcnj11}^{-/} \beta$ cells does not result from altered expressions of genes associated with $G$ protein signaling or amount of the $G$ proteins.

GLP-1, but not GIP, directly activates $G q$ in $\mathrm{Kcnj11}^{-/-} \beta$ cells while neither GLP-1 nor GIP activates Gq in control $\beta$ cells. To ascertain that GLP-1 directly enhances coupling of GLP-1R and Gq, we used the Gq-specific fluorescence resonance energy transfer (FRET) sensor mNG-G $\gamma$-IRES-Gaq-mTq2 (49) (Supplemental Figure 4). We expressed this FRET sensor in parental control (MIN6-K8) and $\mathrm{Kcnj11}^{--} \beta \mathrm{CL} 1$ to monitor activation of $\mathrm{Gq}$ in response to various stimuli. Carbachol $(50 \mu \mathrm{M})$, a positive control of activation of $\mathrm{Gq}$, clearly induced changes in the FRET response in both parental control and $\mathrm{Kcnj11}^{-/} \beta \mathrm{CL} 1$ (Figure 4A), which were blocked by simultaneous application of $100 \mathrm{nM} \mathrm{YM-254890.} \mathrm{Given} \mathrm{these} \mathrm{findings,}$ we conclude that the mNG-G $\gamma$-IRES-Gaq-mTq2 expressed in these cells functions as a Gq FRET sensor. We next compared the responses to GLP-1 $(1 \mathrm{nM})$ in parental control and Kcnj11 ${ }^{-/-} \beta \mathrm{CL} 1$ cells using mNG-G $\gamma$-IRES-G $\alpha$-mTq2. In Kcnj11/- $\beta$ CL1, but not in parental control, GLP-1 induced a FRET response that was comparable in magnitude to that elicited by carbachol, which was abolished by $100 \mathrm{nM}$ YM-254890 (Figure 4B). In contrast, GIP (1 nM) did not alter the FRET response (Figure $4 \mathrm{C}$ ). These results indicate that GLP-1, but not GIP, directly activates Gq in $\mathrm{K}_{\text {ATP }}$ channel-deficient $\beta$ cells and that neither of them activates Gq in normal $\beta$ cells.

Enhanced $G q$ signaling and reduced Gs signaling are commonly found in various models of persistently depolarized $\beta$ cells. $\beta$ Cells of $\beta \mathrm{Kcnj11}^{-/-}$mice are permanently depolarized (Figure $\left.1 \mathrm{~A}\right)$. It has been shown that membrane potential modulates activation of $\mathrm{Gq}$ protein-coupled receptors (GqPCRs) in several cell types, such as neurons and smooth muscle cells (50). We therefore hypothesized that persistent depolarization of $\beta$ cells caused by metabolic, pharmacological, or genetic inactivation of the $\mathrm{K}_{\mathrm{ATP}}$ channels might enhance Gq signaling in $\beta$ cells.

We tested this by chronic culture of WT mouse (B6) islets with high glucose ( $25 \mathrm{mM}$ for 3 days) or the sulfonylurea tolbutamide (500 $\mu \mathrm{M}$ for 5 days) to mimic the conditions in $\beta \mathrm{Kcnj}^{-11^{--}}$mice. $\beta$ Cells in islets cultured under high glucose conditions were likewise depolarized when membrane potential was subsequently measured at low glucose $(1 \mathrm{mM})$, a finding similar to that reported previously (51), and spontaneous low-amplitude action potential firing was observed (Figure 5A). The average membrane potential was approximately $-37 \mathrm{mV}$ at $1 \mathrm{mM}$, and increasing glucose concentration to $10 \mathrm{mM}$ did not produce further depolarization (Figure $5 \mathrm{~B})$. In islets cultured with $5.5 \mathrm{mM}$ glucose, $\beta$ cells responded to high glucose $(10 \mathrm{mM})$ with increased membrane depolarization and generation of large-amplitude action potentials (Figure 5A). The average membrane potential of $\beta$ cells measured at $1 \mathrm{mM}$ glucose was approximately $-66 \mathrm{mV}$, which increased to approximately $-48 \mathrm{mV}$ in the presence of $10 \mathrm{mM}$ glucose (Figure 5B). Basal insulin secretion (at $2.8 \mathrm{mM}$ glucose) was elevated in the high glucose-cultured islets compared with islets cultured with $5.5 \mathrm{mM}$ glucose. While GLP-1IIS was retained in the high glucose-cultured islets, GIPIIS was diminished (Figure 5C).

Similar results were obtained by sulfonylurea treatment of WT islets (Supplemental Figure 5A). In islets treated chronically with 
A

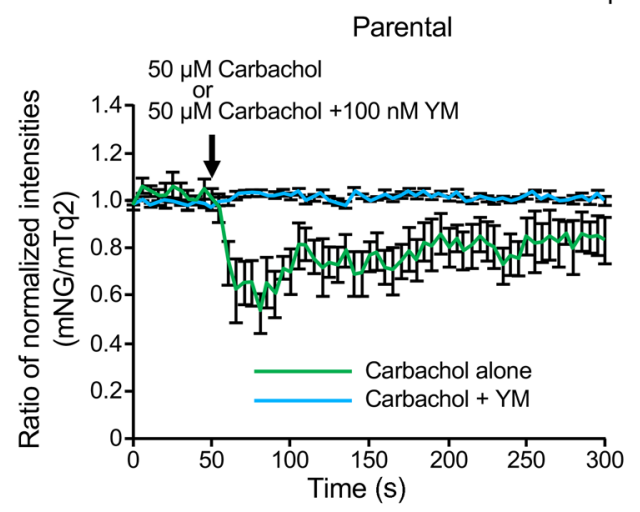

FRET response to carbachol

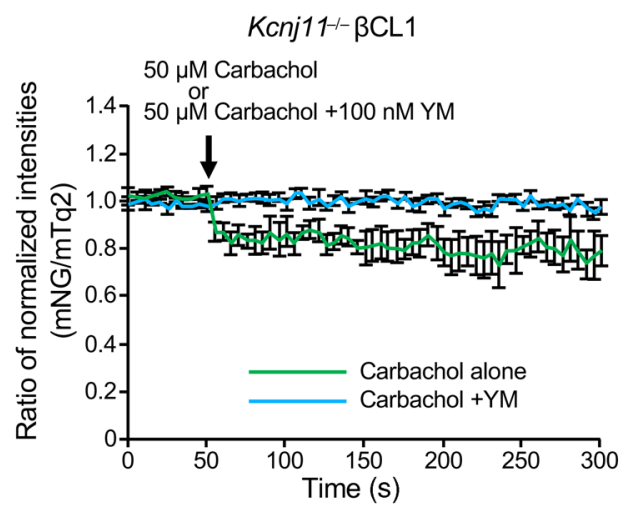

Figure 4. GLP-1, but not GIP, directly activates $\mathrm{Gq}$ in $\mathrm{Kcnj}^{11^{-/-}} \beta$ cells, while neither GLP-1 nor GIP activates

Gq in control $\beta$ cells. (A) Effects of carbachol alone or with YM-254890 on the FRET ratio change in parental control (left) and Kcnj11 ${ }^{-/-} \beta C L 1$ (right). (B) Effects of GLP-1 alone or with $\mathrm{YM}-254890$ on $\mathrm{Gq}$ activation in parental control (left) and $K c n j 11^{-/-}$ $\beta C L 1$ (right). (C) Effects of GIP on Gq activation in parental control (left)

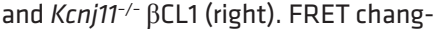
es are expressed as the ratio between donor (mTq2) and acceptor (NG) fluorescence intensities (ratiometric imaging) ( $z$ ) ( $n=10-12$ for each stimulation in $\mathbf{A}-\mathbf{C})$. Data are represented as mean $\pm \mathrm{SEM}$.

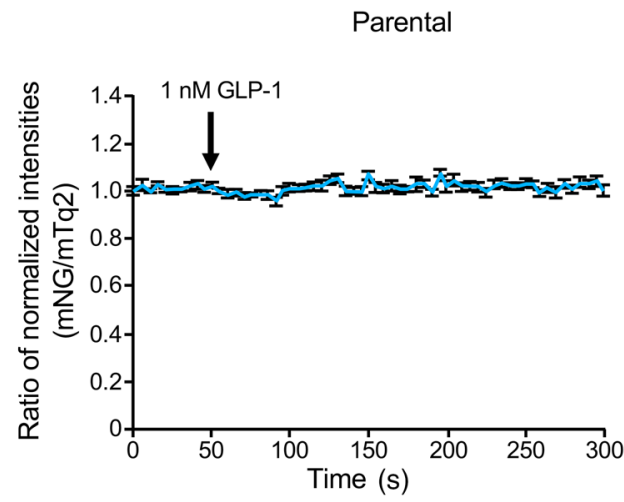

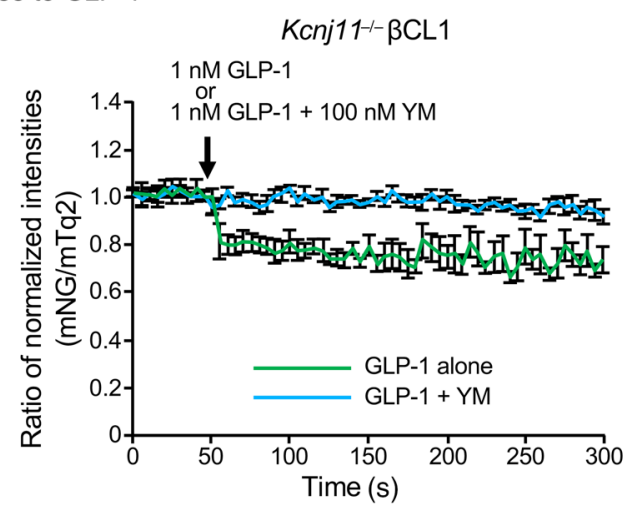

C

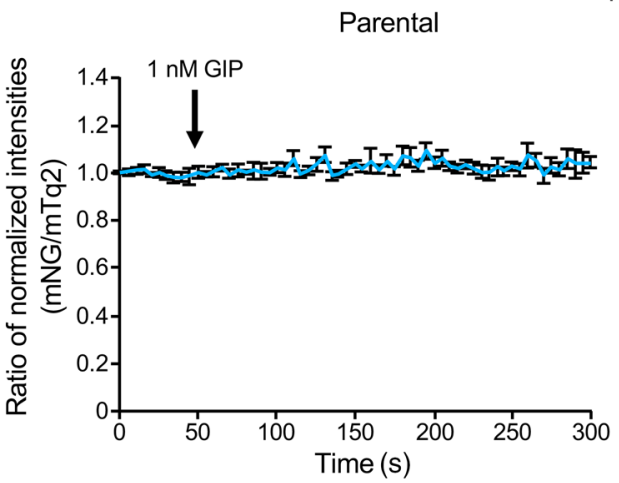

RET response to GIP

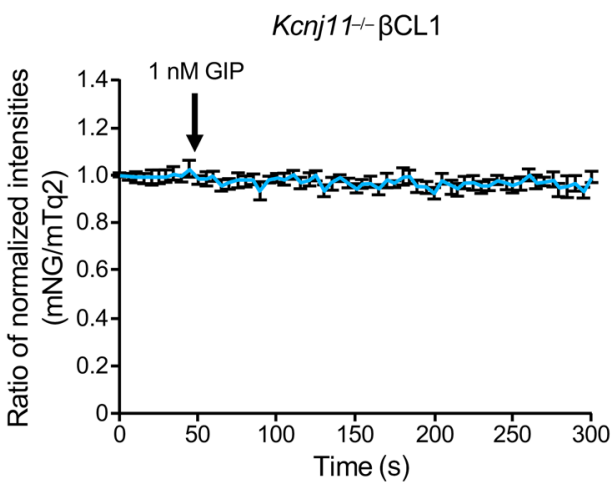

tolbutamide ( $500 \mu \mathrm{M}, 5$ days) the resting membrane potential of $\beta$ cells subsequently measured at $1 \mathrm{mM}$ glucose in the absence of tolbutamide was elevated compared with vehicle-treated islets (approximately $-30 \mathrm{mV}$ vs. approximately $-70 \mathrm{mV}$ ). In these islets, basal insulin secretion was also elevated. No insulin responses to high glucose, enhanced GLP-1IIS, and loss of GIPIIS were observed. None of these effects were seen following short-term treatment with tolbutamide (Supplemental Figure 5B).

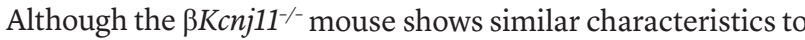
those of T2D, the mouse generated by $\beta$ cell-specific ablation of Kcnj11 with gene technology is a very unique diabetes model. We therefore extended our observations to the KK-Ay mouse, a mouse model of spontaneous obese T2D, which is a product of crossbreeding between obese KK and lethal agouti yellow (Ay) mice and carries heterozygous mutation of the agouti gene (52). $\beta$ Cells from nondiabetic control KK mice responded to high glucose (10
$\mathrm{mM})$ with increased membrane depolarization and firing of largeamplitude action potentials (Figure 5D). The average membrane potential of KK $\beta$ cells exposed to $1 \mathrm{mM}$ glucose was approximately $-80 \mathrm{mV}$, and the membrane potential was increased to approximately $-65 \mathrm{mV}$ when the $\beta$ cells were exposed to $10 \mathrm{mM}$ glucose (Figure 5E). $\beta$ Cells from KK-Ay mice exposed to $1 \mathrm{mM}$ glucose were strongly depolarized compared with those from KK mice (approximately $-30 \mathrm{mV}$ ), and there was no further depolarization by increasing glucose to $10 \mathrm{mM}$ with no clear action potential firing (Figure 5, D and E). We then examined insulin secretory properties of KK and KK-Ay mice (Figure 5F). In isolated islets from KK mice, GIIS, GLP-1IIS, and GIPIIS were similar to those observed

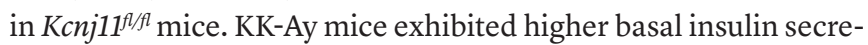
tion than that in KK mice. Increasing glucose from 2.8 to $11.1 \mathrm{mM}$ stimulated insulin secretion in KK-Ay mice, but the effect of high glucose was limited to $50 \%$ stimulation, much less than the $500 \%$ 
A

Electrical activity of wild-type mouse $\beta$-cells

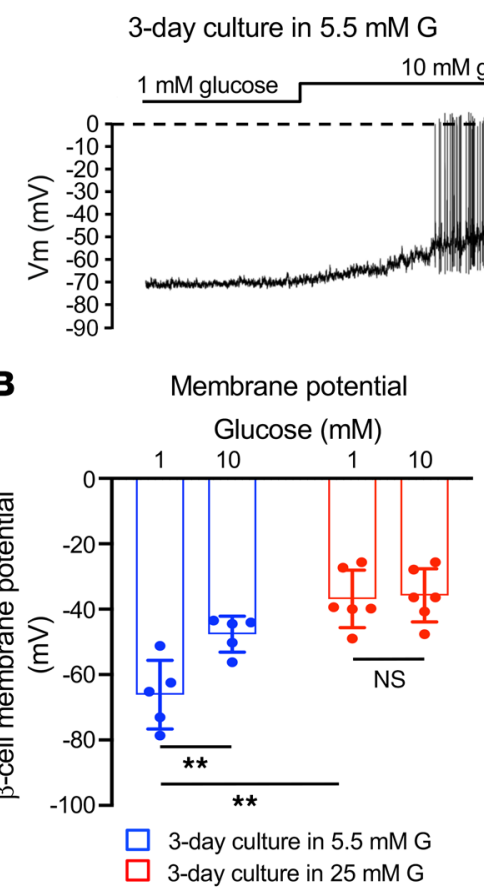

3-day culture in $25 \mathrm{mM} \mathrm{G}$ $10 \mathrm{mM}$ glucose

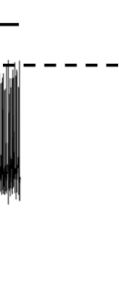

C

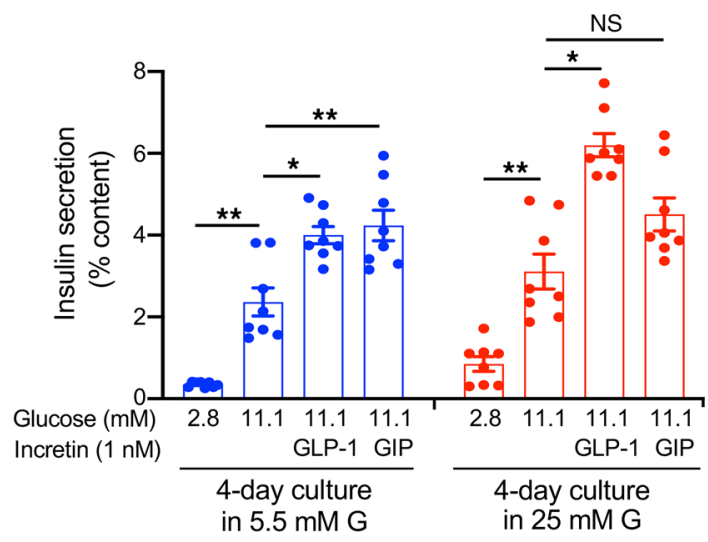

D

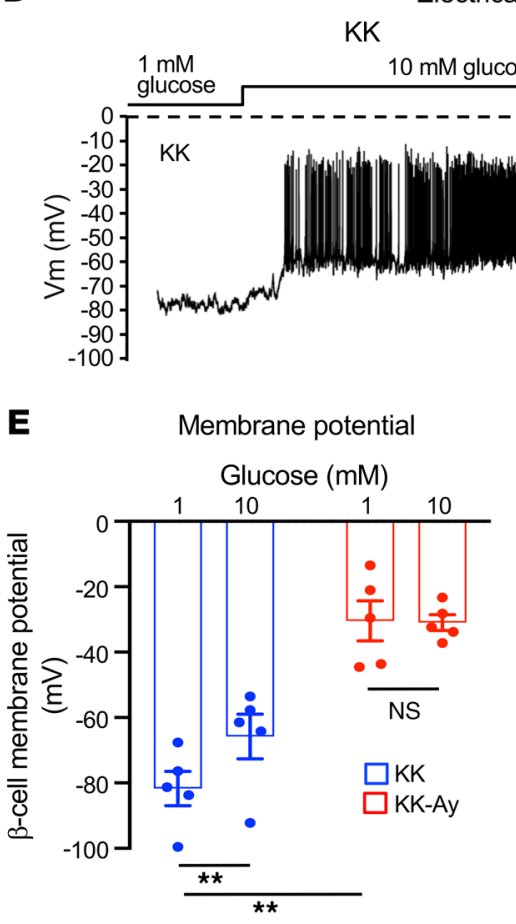

Electrical activity of KK and KK-Ay mouse $\beta$-cells

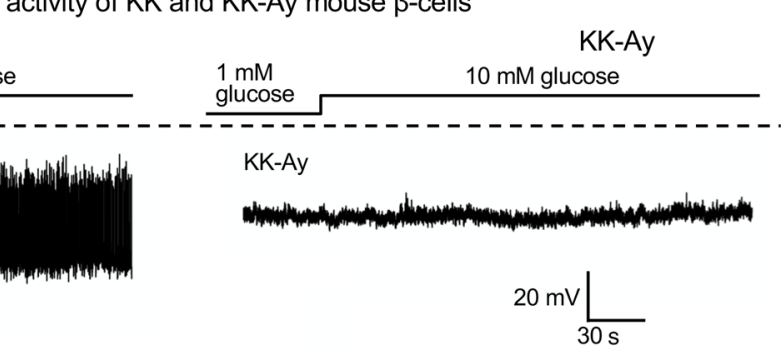

Figure 5. $\beta$ Cell membrane potential and insulin secretion from islets in various models of $\beta$ cell persistent depolarization. (A) Representative traces of electrophysiological recordings of primary $\beta$ cells of WT mice. Recordings were made in the presence of $1 \mathrm{mM}$ glucose after chronic (3 days) culture of WT mouse islets in normal glucose (5.5 $\mathrm{mM}$ ) or high glucose $(25 \mathrm{mM})$. G, glucose. (B) Membrane potential of primary $\beta$ cells of WT mice measured under the same conditions as described in A ( $n=5-6$ for each condition). (C) Insulin secretion from WT mouse islets. Insulin secretion was measured after chronic (4 days) culture of WT mouse islets in 5.5 $\mathrm{mM}$ (blue) or $25 \mathrm{mM}$ (red) glucose ( $n$ $=8$ for each condition). (D) Representative traces of electrophysiological recordings of primary $\beta$ cells of KK and KK-Ay mice. Recordings were made in the presence of glucose at the concentrations indicated. (E) Membrane potential of primary $\beta$ cells of KK and KK-Ay mice. Membrane potential was measured in the presence of glucose at concentrations indicated ( $n=6$ for each condition). (F) Insulin secretion from the islets of KK and KK-Ay mice ( $n=$ 6-8 for each condition). Statistical analyses were performed by 2-way ANOVA (B, C, E, and F), followed by Tukey's post hoc test (C and $\mathbf{F}$ ). Data are represented as mean \pm SEM. ${ }^{*} P<0.05 ;{ }^{* *} P<0.01$.

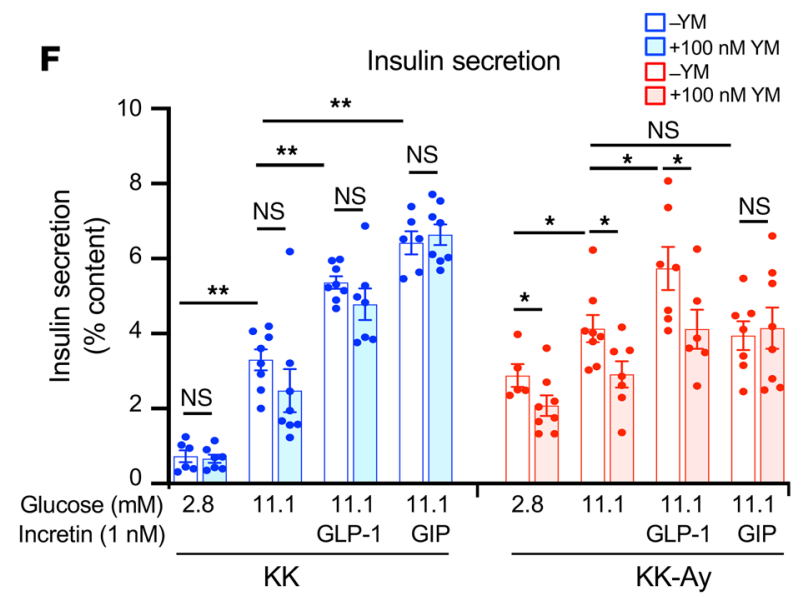

observed in KK mice. It should be noted, however, that a membrane potential of $-30 \mathrm{mV}$ is sufficient to activate VDCCs in $\beta$ cells, explaining the stimulation of insulin secretion despite the apparent lack of regenerative electrical activity in KK-Ay islets. While GLP-1 amplified GIIS, GIP was ineffective in KK-Ay islets. The amplifying effect of GLP-1 on GIIS was abolished by YM-254890 $(100 \mathrm{nM})$ in KK-Ay islets, but this compound had no effect in KK islets. Overall, data from hyperglycemic KK-Ay mice corroborate the findings in $\beta \mathrm{Kcnj} 11^{-/-}$islets and WT islets chronically exposed to high glucose or sulfonylurea.

Chronic treatment of human islets with high glucose stimulates electrical activity of $\beta$ cells and basal insulin secretion. We extended these observations to human islets using the high-glucose culture protocol. Human islets were cultured at 5.5 or $16.7 \mathrm{mM}$ glucose for 
A Electrical activity of human $\beta$-cells

3-day culture in $5.5 \mathrm{mM} \mathrm{G}$

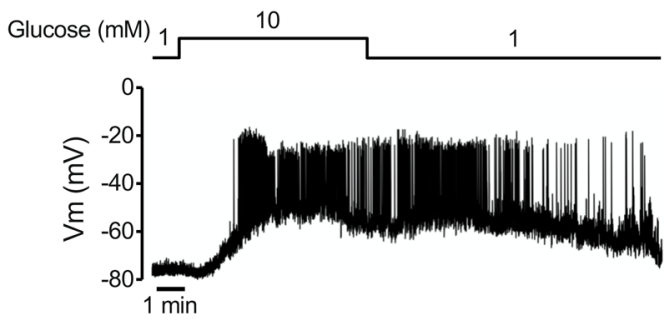

3-day culture in $16.7 \mathrm{mM} \mathrm{G}$

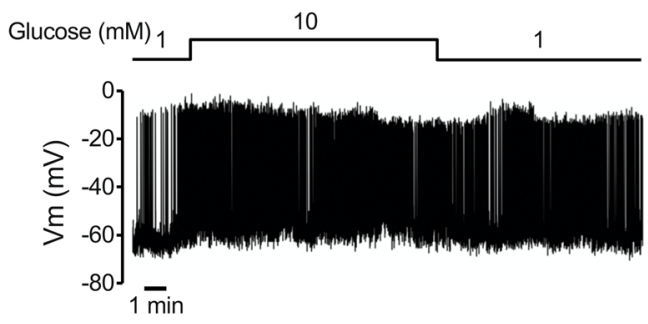

3-day culture in $16.7 \mathrm{mM} \mathrm{G}+50 \mathrm{nM}$ YM

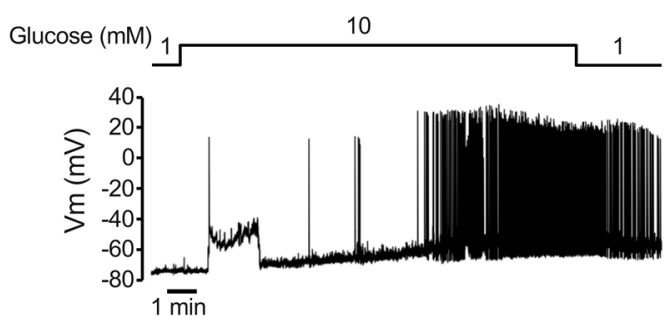

B Membrane potential of human $\beta$-cells
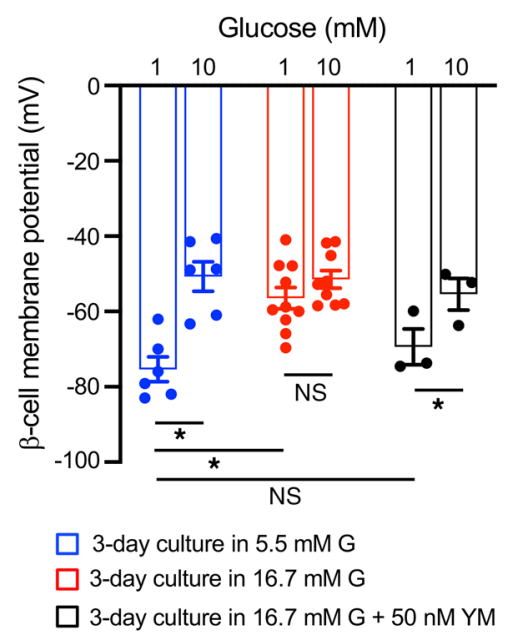

C Insulin secretion from human islets

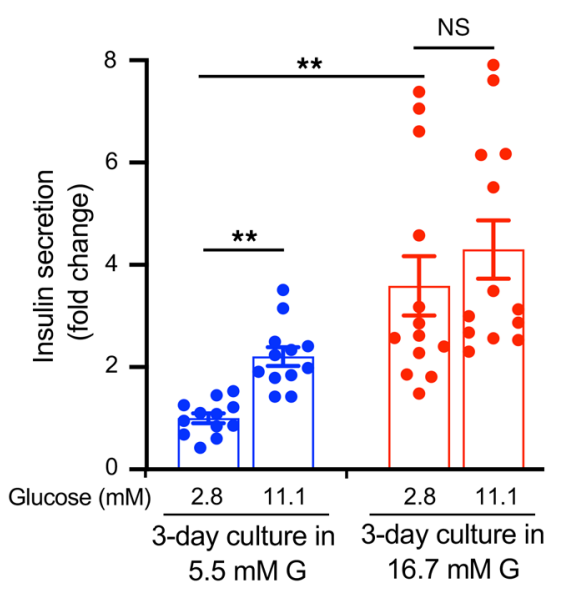

Figure 6. $\beta$ Cell membrane potential and insulin secretion from chronic high glucose-treated human islets. (A) Representative traces of electrophysiological recordings of primary human $\beta$ cells. Recordings were made in the presence of $1 \mathrm{mM}$ and $10 \mathrm{mM}$ glucose, following chronic (3 days) culture in normal glucose (5.5 mM), high glucose (16.7 mM), or high glucose (16.7 mM) plus YM-254890 (50 nM). (B) Membrane potential of primary human $\beta$ cells. Recordings were made in the $\beta$ cells under the same condition as described in A ( $n=3-10$ for each condition). (C) Insulin secretion from nondiabetic human islets. Insulin secretion in response to glucose following 3-day culture in 5.5 or $16.7 \mathrm{mM}$ glucose is shown. Insulin secretion was normalized by the value at $2.8 \mathrm{mM}$ glucose $(=1)$ in the islets cultured in $5.5 \mathrm{mM}$ glucose for 3 days ( $n=13-14$ for each condition). Pooled data from 4 independent experiments from 4 donors are shown. Statistical analyses were performed by 2-way ANOVA followed by Tukey's post hoc test. Data are represented as mean \pm SEM. ${ }^{*} P<$ $0.05 ;{ }^{* *} P<0.01$.
3 days. In islets cultured at $5.5 \mathrm{mM}$ glucose, the $\beta$ cell membrane potential in islets exposed to $1 \mathrm{mM}$ glucose averaged approximately $-75 \mathrm{mV}$ and $\beta$ cells responded to $10 \mathrm{mM}$ glucose with membrane depolarization and action-potential firing (Figure 6, A and B). In islets cultured at $16.7 \mathrm{mM}$ glucose, $\beta$ cells were depolarized at 1 $\mathrm{mM}$ glucose, the membrane potential averaged approximately $-55 \mathrm{mV}$ (Figure 6, A and B), and spontaneous electrical activity was observed in 8 of the 9 cells tested (Figure 6A). Increasing glucose concentration to $10 \mathrm{mM}$ did not produce significant further increase in depolarization or stimulation of electrical activity (Figure 6, A and B). The effects of high-glucose culture on electrical activity were reversed by culturing the islets at high glucose in combination with YM-254890 (50 nM); the membrane potential of these cells was similar to that of $\beta$ cells cultured at $5.5 \mathrm{mM}$ glucose, and they responded to high glucose with membrane depolarization and regenerative electrical activity (Figure 6, A and B).

We also monitored $\left[\mathrm{Ca}^{2+}\right]_{\mathrm{i}}$ in intact human islets (Supplemental Figure 6A). In islets cultured at $5.5 \mathrm{mM}$ glucose, only a small number (10\%-15\%) of cells showed spontaneous activity at $1 \mathrm{mM}$ glucose and may represent $\alpha$ cells, which are spontaneously active at low glucose (53). The majority of cells were silent at low glucose, but increasing glucose to $11 \mathrm{mM}$ induced increased $\left[\mathrm{Ca}^{2+}\right]_{i}$. In islets cultured at high glucose $(16.7 \mathrm{mM})$ for 3 days, spontaneous activity at $1 \mathrm{mM}$ glucose was much higher (in the experiment shown, nearly $100 \%$ of cells were active) than in those cultured at $5.5 \mathrm{mM}$, and increasing glucose to $11 \mathrm{mM}$ exerted no further stimulatory effect. While some of these cells may represent non- $\beta$ cells, the activity of $\beta$ cells at low glucose is clearly increased in islets cultured at high glucose. The responses shown are representative of 3 islets from each of the 4 donors analyzed.

We correlated these effects to insulin secretion (Figure 6C). Islets cultured at $5.5 \mathrm{mM}$ glucose for 3 days responded to elevation of glucose from $2.8 \mathrm{mM}$ to $11.1 \mathrm{mM}$ with an increase in insulin secretion by $125 \%$. In islets cultured at $16.7 \mathrm{mM}$ glucose for 3 days, basal secretion at $2.8 \mathrm{mM}$ glucose was increased by more than $200 \%$, and increasing glucose to $11.1 \mathrm{mM}$ caused only a slight increase in insulin secretion $(<30 \%)$ that did not reach statistical significance.

The Gq-specific agonist MK-2305 improves glucose tolerance in $\beta \mathrm{Kcnj11}^{-/-}$mice and KK-Ay mice. To determine whether enhanced $\mathrm{Gq}$ signaling in $\beta$ cells contributes to improvement of the diabetic state in vivo, we examined the effect of the Gq-specific agonist MK-2305 $(10 \mathrm{mg} / \mathrm{kg})$ on glucose tolerance in $\beta \mathrm{Kcnj11}^{-/-}$mice and KK-Ay mice. Oral administration of MK-2305 to $\beta \mathrm{Kcnj11}^{-/-}$mice before oGTT normalized fasting hyperglycemia and markedly improved glucose 
A oGTT in Kcnj1 $11^{1 / / f l}$ and $\beta K c n j 11^{-/-}$mice

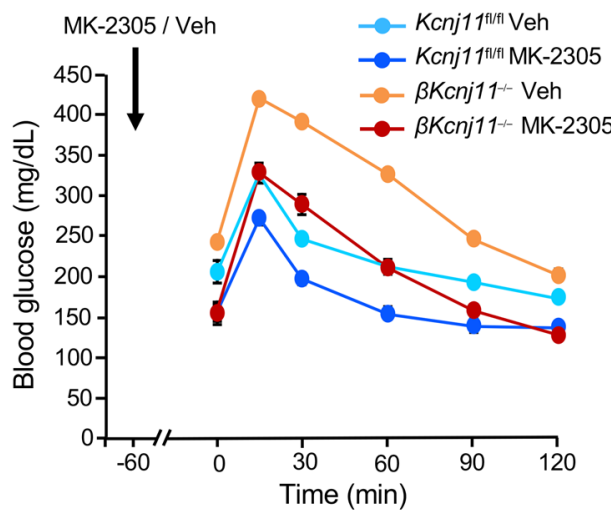

B OGTT in KK-Ay mice
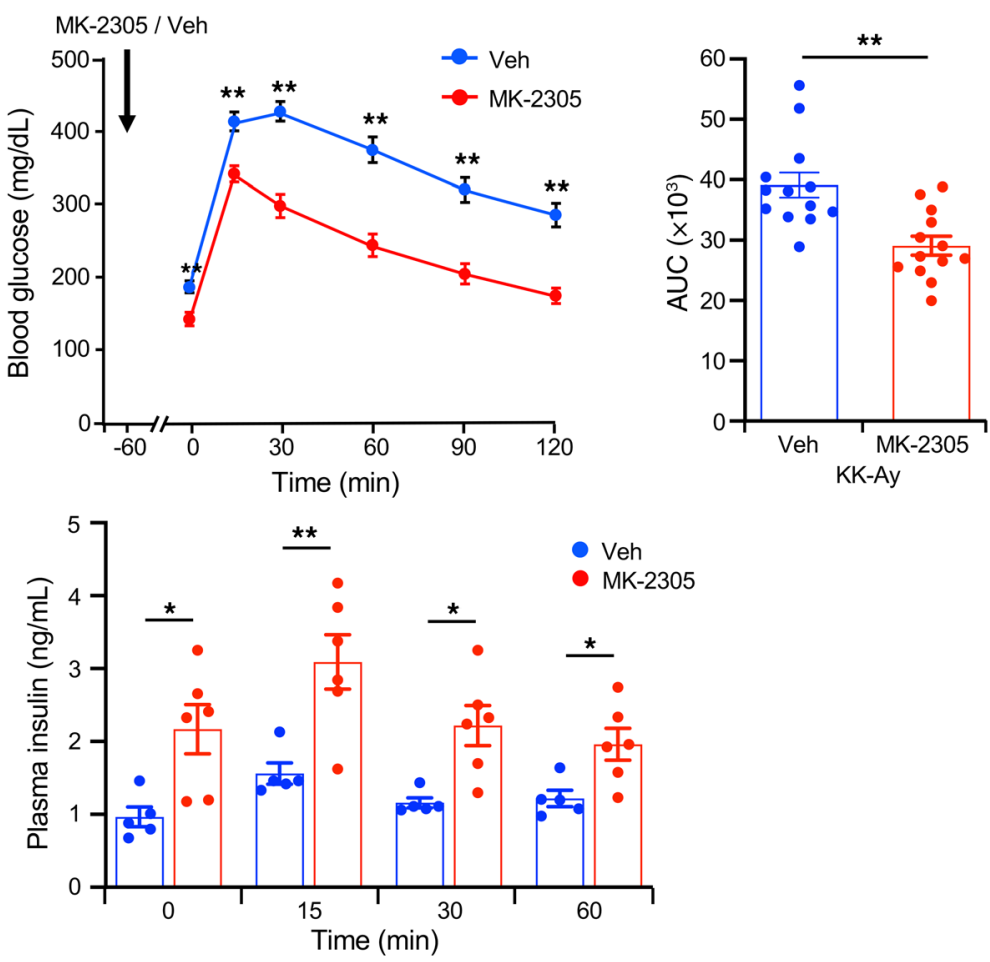

tolerance in the mice (Figure 7A). Similarly, MK-2305 significantly improved fasting hyperglycemia as well as glucose tolerance and increased plasma insulin levels in KK-Ay mice (Figure 7B). These results suggest that $\mathrm{Gq}$-specific agonists are effective in ameliorating diabetes by amplifying insulin secretion.

\section{Discussion}

Insulin secretion from pancreatic $\beta$ cells is essential for the maintenance of normoglycemia. Impaired insulin secretion is a hallmark of T2D. Modulation of GIIS by neuronal and hormonal inputs is critical for the adjustment of insulin secretion in response to various metabolic demands (9). Among these, the incretins GLP-1 and GIP are particularly important. They prevent postprandial hyperglycemia by amplification of insulin secretion upon meal ingestion (11-17). $\mathrm{K}_{\mathrm{ATP}}$ channels in $\beta$ cells transduce changes in blood glucose, via acceleration of glucose metabolism, into electrical activity required for the release of insulin $(1,5)$. Since the incretin-medi-
Figure 7. Gq-specific agonist MK-2305 improves

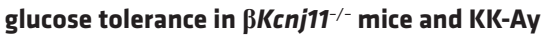
mice. (A) OGTT following MK-2305 administration in $\beta K c n j 11^{-/-}$mice (left) and AUC (right) ( $n=6-15$ per group). (B) oCTT following MK-2305 administration in KK-Ay mice (upper left) and AUC (upper right) ( $n=13$ for both groups) and plasma insulin levels during oGTT (lower) ( $n=5-6$ per group). MK-2305 $(10 \mathrm{mg} / \mathrm{kg}$ ) was administered orally to mice 60 minutes before glucose challenge $(1.5 \mathrm{~g} / \mathrm{kg})$. Veh, vehicle (carboxymethyl cellulose). Statistical analyses were performed by 2-way ANOVA followed by Dunnett's post hoc test and by Student's unpaired $t$ test $(\mathbf{A}$ and $\mathbf{B})$. Data are represented as mean \pm SEM. ${ }^{*} P<0.05 ;{ }^{* *} P<0.01$.

ated amplifying pathways are effective only when GIIS is operative, these pathways are also dependent on the activity of the $\mathrm{K}_{\mathrm{ATP}}$ channels (1). Although GLP-1IIS and GIPIIS are both required to maintain blood glucose levels within normal range in healthy subjects, the reason why only GLP-1-based treatments are effective in diabetes remains unknown.

We previously reported that gKcnj11/mice exhibited only slight glucose intolerance despite a severe defect in GIIS in vivo (29). While the in vitro insulin response to GLP-1 was retained to some extent in gKcnj11/islets, that to GIP was markedly reduced (31). These phenotypic changes in $\mathrm{gKcnj11^{-/ } \text { mice }}$ were due not only to $\mathrm{K}_{\text {ATP }}$ channel deficiency in the $\beta$ cells, but also to deficiency of the channels in other cell types/tissues, as the channels are expressed in many cell types, including non- $\beta$ cells in the islets, skeletal muscle, enteroendocrine cells, heart, and brain $(7,8)$. For example, increased glucose uptake by skeletal muscles was found in the gKcnj11- mice, which may have ameliorated the expected hyperglycemic effect expected from the loss of GIIS (30). Thus, the direct role of $\beta$ cell $\mathrm{K}_{\mathrm{ATP}}$ channels in insulin secretion and glucose homeostasis has not yet been clarified. To address this issue, we generated mice lacking $\mathrm{K}_{\mathrm{ATP}}$ channels specifically in $\beta$ cells ( $\beta$ Kcnj11 $1^{-}$mice). This mouse model is similar in characteristics to those of human T2D: (a) fasting hyperglycemia and impaired glucose tolerance; (b) impaired insulin response to glucose; (c) retained GLP-1 effect, but diminished GIP effect, on amplification of insulin secretion; and (d) ability of GLP-1 (but not GIP) to restore normal glucose tolerance.

We confirm that both GLP-1 and GIP amplify insulin secretion

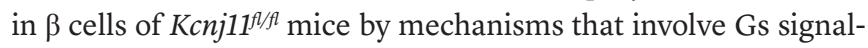
ing, whereas only GLP-1 amplifies insulin secretion in $\beta$ cells of

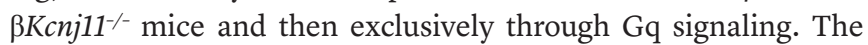
change in $G$ protein signaling in persistently depolarized $\beta$ cells may be of therapeutic and pathophysiological significance, as it explains how the insulinotropic effect of GLP-1 is maintained in 
T2D, but that of GIP is lost. This is because GLP-1 activates both Gs and Gq in $\beta$ cells, while GIP activates only Gs. These findings are supported using other experimental paradigms associated with persistent membrane depolarization of $\beta$ cells due to $\mathrm{K}_{\text {ATP }}$ channel inactivation, such as diabetic/hyperglycemic mice as well as mouse and human pancreatic islets chronically treated with high glucose or sulfonylurea. We also show that the stimulation of insulin secretion by agents that operate through Gq signaling is enhanced in persistently depolarized $\beta$ cells.

Changes in membrane potential are known to directly modulate activation of GPCRs, especially class A GPCRs $(50,54,55)$. Although the mechanisms by which membrane potential modulates GPCRs are not fully understood, recent studies have shown that allosteric effects of $\mathrm{Na}^{+}$ion on class A GPCRs modulate GPCR activation and GPCR-mediated signaling (54-56). Binding of voltage-driven translocated $\mathrm{Na}^{+}$to the highly conserved aspartic acid residue in transmembrane domain $2\left(\mathrm{Asp}^{2.50}\right)$ in class A GPCRs, combined with the effects of the $\mathrm{Na}^{+}$-coordinating residues, modulates GPCR agonist binding and activation. In addition, $\mathrm{Na}^{+}-$ coordinating residues and $\mathrm{Na}^{+}$itself could also lead to selectivity of distinct GPCR-mediated signaling pathways (so called "signaling bias"), as exhibited by the $\delta$ opioid receptor (57). Allosteric modulation of class B GPCRs has also been studied (58), but their modulation by membrane potential remains unknown. A mechanism similar to that in class A GPCRs has recently been proposed for class B GPCRs as well, based on a study of the glucagon receptor as a model (59). In this model, binding of $\mathrm{Na}^{+}$to residues at $\mathrm{Asn}^{3.43 \mathrm{~b}}$, Glu ${ }^{6.53 \mathrm{~b}}$, and $\mathrm{Gln}^{7.49 \mathrm{~b}}$ (60) is thought to be important for allosteric modulation of the glucagon receptor by $\mathrm{Na}^{+}$. Notably, all these residues are conserved in glucagon, GLP-1, and GIP receptors (60). Although allosteric effects of $\mathrm{Na}^{+}$on GLP-1 and GIP receptors are yet to be clarified, it is possible that persistent depolarization of $\beta$ cells induces signaling bias as well as modulation of the activities of GLP-1R and GIP receptor. In support of this are the findings that modulation of class A GPCR activities by membrane potential differs by depending on the GPCR itself, agonist, and cell type (50). For example, whereas depolarization reduces the activity of the M2 receptor $\left(\mathrm{G}_{\mathrm{i} / \mathrm{O}} \mathrm{PCR}\right)$, it enhances the activity of the $M 1$ receptor $\left(G_{q} P C R\right)(61)$. Given that $\mathrm{Na}^{+}$resident time in the binding site is very short, it seems reasonable that persistent, but not transient, depolarization of $\beta$ cells leads to a switch from $G$ s to Gq signaling. Elevated $\mathrm{Ca}^{2+}$ level in $\beta$ cells may also contribute to enhanced downstream signaling of $\mathrm{Gq}$ through activation of phospholipase C, as has been reported in insulin-secreting INS-1 cells (62). Further studies are required to elucidate the mechanisms by which membrane potential modulates GLP-1 and GIP receptor activities and their downstream signals.

Based on our findings, we propose the following model to explain differential modulation of insulin secretion by GPCRs (Figure 8). In resting $\beta$ cells, insulin secretion is low under basal conditions (low glucose and no activation of GPCRs) because of high $\mathrm{K}_{\text {ATP }}$ channel activity (Figure $8 \mathrm{~A}$ ). Under a stimulated state (high glucose, high levels of ligands for GPCRs), $\mathrm{K}_{\mathrm{ATP}}$ channels are closed and the resulting membrane depolarization causes opening of VDCCs and stimulation of insulin secretion. Under this condition, GLP-1 and GIP both activate Gs and increase cAMP production, thereby amplifying insulin secretion through PKA- and
Epac2-dependent pathways $(63,64)$ (Figure 8B). In persistently depolarized $\beta$ cells (regardless of this being a consequence of genetic, pharmacological, or metabolic intervention leading to reduced $\mathrm{K}_{\text {ATP }}$ channel activity), Gq signaling (i.e., the DAG/PKC pathway and the $\mathrm{IP}_{3} / \mathrm{Ca}^{2+}$ pathway) is enhanced even at basal state. This contributes to further inhibition of the $\mathrm{K}_{\mathrm{ATP}}$ channels (65) and activation of a depolarizing background conductance (41), leading to sustained elevation of $\left[\mathrm{Ca}^{2+}\right]_{i}$. As a result, basal secretion of insulin is stimulated (Figure $8 \mathrm{C}$ ), which disables the normal metabolic regulation of insulin secretion. In such persistently depolarized $\beta$ cells, GLP-1 or other ligands for GqPCRs (such as muscarinic agonist and fatty acids) further enhance $\mathrm{Gq}$ signaling and amplify insulin secretion (Figure 8D). Indeed, we have shown that the Gq agonist MK-2305 drastically improves glucose tolerance and insulin secretion in vivo in the KK-Ay mouse, a model of $\mathrm{T} 2 \mathrm{D}$, as well as glucose tolerance in $\beta \mathrm{Kcnj11}^{-/-}$mice (Figure 7, A and B). This concept is supported by the finding that the Gq-specific inhibitor YM-254890 reduced basal insulin secretion and restored normal glucose regulation of $\beta$ cell electrical activity (Figure 3C and Figure 6, A and B). In contrast, the amplifying effect of GIP on insulin secretion is diminished because Gs signaling is suppressed in persistently depolarized $\beta$ cells. GLP-1Rs can couple to both Gs and $\mathrm{Gq}$ in various cell types, including $\beta$ cells $(36,40,41)$, but there is no evidence that GIP receptors can couple to Gq.

Together, these findings explain the differential effects of GLP-1 and GIP in the amplification of insulin secretion in persistently depolarized $\beta$ cells. Although precise molecular mechanisms remain to be elucidated, it is clear that there is a switch from Gs to Gq signaling in persistently depolarized $\beta$ cells. Our findings clarify why GLP-1- but not GIP-based therapies are effective in T2D and also provide a mechanism accounting for the increase in basal insulin secretion that is a characteristic feature of the disease (i.e., chronic hyperglycemia leads to reduced $\mathrm{K}_{\mathrm{ATP}}$ channel activity that leads to stimulation of $\beta$ cell electrical activity, which leads to activation of $\mathrm{Gq}$, thereby resulting in elevated basal insulin secretion).

These findings have immediate therapeutic implications for T2D. Since membrane depolarization resulting from reduced $\mathrm{K}_{\mathrm{ATP}}$ channel activity in hyperglycemia diminishes Gs signaling, normalization of membrane potential of $\beta$ cells by reactivation of $\mathrm{K}_{\text {ATP }}$ channels could improve GIPIIS through restored Gs signaling. This may explain the beneficial effects of therapeutic interventions that result in reduced plasma glucose, such as calorie restriction (66). In this context, it is noteworthy that the insulinotropic effects of endogenous GIP are reestablished after lowering blood glucose by treatment with insulin (67) or sodium-dependent glucose transporter-2 (SGLT-2) inhibitors (68).

In summary, the present data demonstrate that, while Gs is the primary signal for amplification of GIIS in normal $\beta$ cells, Gq is the primary signal for the amplification in $\beta$ cells persistently depolarized by $\mathrm{K}_{\text {ATP }}$ channel inactivation, such as that found in diabetes. They also demonstrate that a Gs-to-Gq signaling switch determines the differential efficacies of GLP-1 and GIP in improvement of glucose tolerance as well as the amplification of insulin response to glucose in the diabetic state. In addition, Gq-specific agonists are effective amplifiers of insulin secretion in persistently depolarized $\beta$ cells. Although the mechanisms underlying the switch require detailed analyses by structural biology in 
A

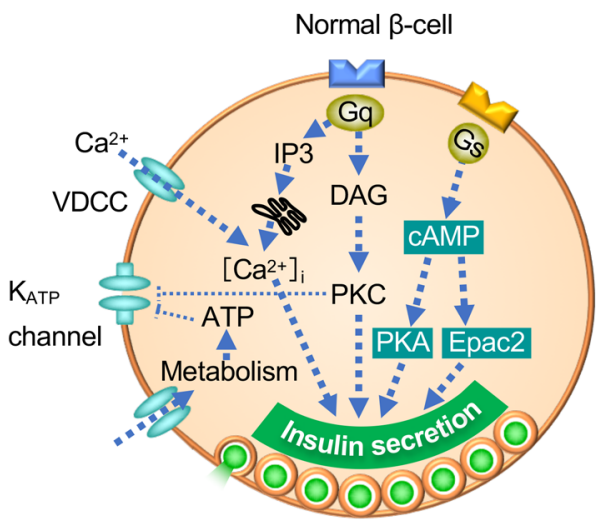

(Basal)

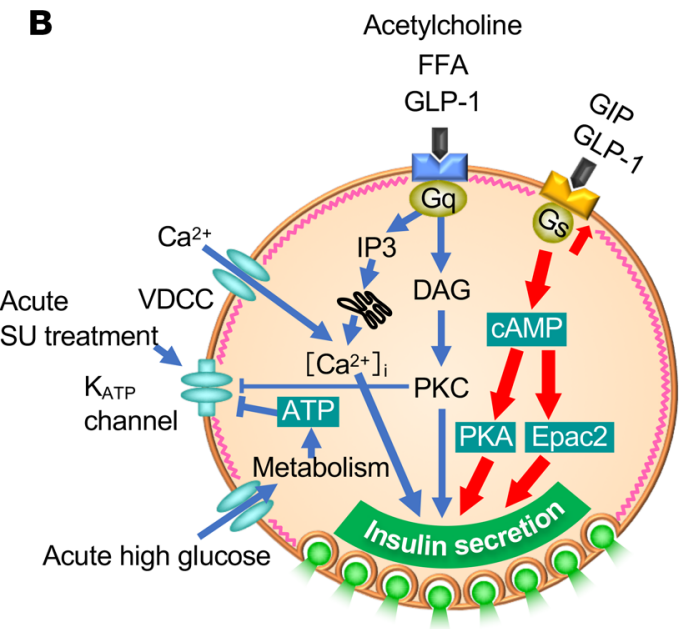

(Stimulated)
C Persistently depolarized $\beta$-cell

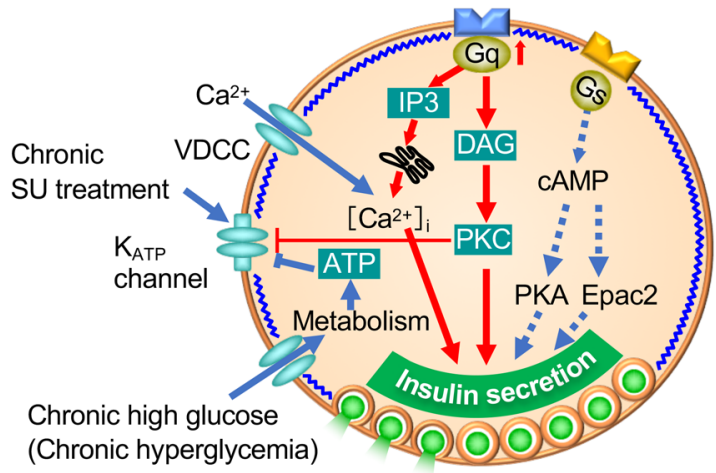

(Basal)

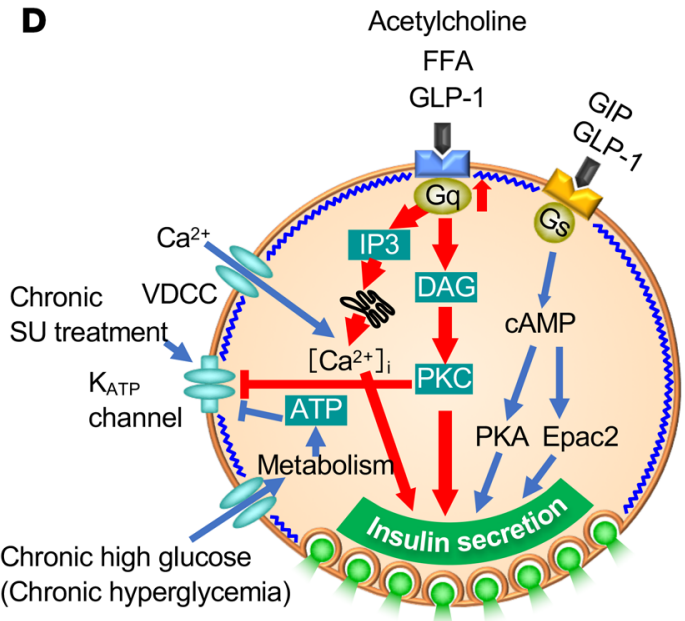

(Stimulated)

\footnotetext{
GqPCRs

GsPCRs

mun Transient depolarization

мим Persistent depolarization
}

Figure 8. Model of a Gs-to-Gq signaling switch for amplification of insulin secretion in persistently depolarized $\beta$ cells. (A and B) for normal $\beta$ cell; (C and D) for persistently depolarized $\beta$ cell. SU, sulfonylurea; FFA, free fatty acids; GqPCRs, Gq protein-coupled receptors; GsPCRs, Gs protein-coupled receptors. Basal and GPCR-stimulated states are shown. See text for details.

combination with site-directed mutagenesis and molecular docking simulation, the present findings provide important leads for the development of insulin secretion-based T2D therapies.

\section{Methods}

Additional details are provided in Supplemental Methods.

Animals. Mice were housed, 2 to 3 per cage, under specific pathogen-free conditions at $23 \pm 2{ }^{\circ} \mathrm{C}$ and $55 \% \pm 10 \%$ relative humidity with a 12-hour light/12-hour dark cycle, and were freely provided with water and commercially obtained CE-2 diet (CLEA Japan Inc.). The numbers of animals studied per genotype are indicated for each experiment.

Generation of $\beta \mathrm{Kcnj11}^{-/-}$mice. Kcnj11/1/+ mice were generated so as to have the Kncj11 gene flanked by 2 loxP sites (Supplemental Figure 1A). The targeting vector was constructed by inserting 2 loxP sites: one into the promoter region and the other into the $3^{\prime}$ untranslated region of the single-exon Kncj11 gene. The embryonic stem (ES) cells with homologous recombination were used to generate the mice car- rying the loxP+Neo allele. Then, the $\mathrm{Neo}^{\mathrm{r}}$ cassette of these mice was deleted, leading to the establishment of $K c n j 11^{f /+}$ mice. $\beta \mathrm{Kcnj}^{\mathrm{j}} 11^{-/-}$mice, $\beta$ cell-specific Kcnj11-KO mice, were generated by crossing Kcnj11/1/fl mice with RIP-Cre ${ }^{+}$mice (32) (a gift from Pedro L. Herrera, Department of Morphology, University of Geneva Medical School, Geneva, Switzerland), as described in Supplemental Figure 1A. All experiments were performed using age-matched control and $\beta \mathrm{Kcnj} 11^{-/-}$mice aged between 11 weeks and 19 weeks.

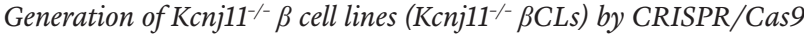
system and cell culture. Kcnj11 ${ }^{-/} \beta$ cell lines were generated from the parental MIN6-K8 $\beta$ cell line, which was previously generated in our lab (69) by the CRISPR/Cas9 system as previously reported (45). In brief, MIN6-K8 cells were reverse transfected with a combination of the Cas9 D10A nickase expression vector and a pair of L/R-sgRNA vectors $(0.133 \mu \mathrm{g} / \mathrm{mL}$ for each) using Lipofectamine 2000 transfection reagent according to the manufacturer's instructions. After 48 hours of incubation, $400 \mu \mathrm{g} / \mathrm{mL}$ hygromycin B was added for selec- 
tion. After 4 days of incubation, cells were replated to recover for 11 days. For clonal isolation, cells were serially diluted in $10 \mathrm{~cm}$ dishes to form single colonies, which were then manually hand-picked under microscopy and expanded. For sequencing, genomic DNA was extracted from each colony using SimplePrep Reagent for DNA (Takara Bio) according to the manufacturer's instruction. Cas9 target regions were amplified by PCR, and the PCR products were subjected to agarose gel electrophoresis. The PCR products showing different lengths from the WT allele were cloned into the pMD20-T blunt vector (Takara Bio) and analyzed by Sanger sequencing using the 3100-Avant Genetic Analyzer (Applied Biosystems). Parental MIN6-K8 was used as controls. The cell lines were grown in high-glucose DMEM containing $10 \%$ heat-inactivated FBS and maintained in a humidified incubator with $95 \%$ air and $5 \% \mathrm{CO}_{2}$ at $37^{\circ} \mathrm{C}$.

Glucose tolerance test. For all glucose tolerance tests (oGTT or i.p.GTT), mice were fasted for 6 hours. Basal blood glucose was sampled at -15 minutes, and glucose was administered as an oral gavage or by i.p. injection at a dose of $1.5 \mathrm{~g} / \mathrm{kg}$ body weight. Blood samples were obtained from the tail vein. For measurements of plasma insulin, GLP-1, and GIP, blood was collected in heparinized syringes and placed into a tube containing an inhibitor cocktail mixture of $\mathrm{KR}$ 62436, EDTA, and aprotinin. Blood glucose levels were measured by the Antsense III Glucose Analyzer (Horiba), and plasma insulin, total GLP-1, total GIP, active GLP-1, and active GIP were determined by their respective ELISA kits.

Measurements of insulin secretion. For measurement of insulin secretion from mouse pancreatic islets, the islets were isolated from mice by collagenase digestion, as described previously (70), and cultured for 2 days, or as indicated in the Figure 5 and 6 legends. Insulin-secretion experiments from mouse islets and cell lines was performed as previously described (71). Insulin released and content was determined by homogeneous time-resolved fluorescence assay (HTRF) using the Insulin UltraSensitive HTRF Assay Kit (Cisbio). The amount of insulin secretion was normalized by islet insulin content. For measurement of insulin secretion from perfused pancreases, perfusion experiments were performed as previously described (28). Briefly, overnight-fasted (16 hours) male mice 12 to 20 weeks of age were used. The perfusion protocol began with a 20-minute equilibration period with the same buffer used in the initial step shown in the figures. The flow rate of the perfusate was $1 \mathrm{~mL} / \mathrm{min}$. The insulin levels in the perfusate were measured by HTRF using the Insulin UltraSensitive HTRF Assay Kit (Cisbio). For measurement of insulin secretion from human islets, human islets were maintained in culture for up to 3 days in RPMI containing 5 or $16.7 \mathrm{mM}$ glucose. Experiments were conducted using batches of 13 to 15 hand-picked and size-matched islets per tube (in triplicate). Following culture for 3 days, islets were washed twice in RPMI before preincubation in KRBB containing $2 \mathrm{mg} / \mathrm{mL}$ BSA (S6003, Sigma-Aldrich) and $2.8 \mathrm{mM}$ glucose for 1 hour at $37^{\circ} \mathrm{C}$. Following this, islets were incubated in $0.3 \mathrm{~mL} \mathrm{KRBB}$ with $2 \mathrm{mg} / \mathrm{mL}$ BSA supplemented with various glucose concentrations or compounds for 1 hour. Insulin secretion was assayed using Meso Scale Discovery or Mercodia human insulin kits.

Measurements of glucagon secretion. Pancreatic islets were isolated and prepared as for insulin above, except that they were preincubated in KRBB containing $16.7 \mathrm{mM}$ glucose. Glucagon released in the incubation buffer and islet glucagon content was measured by the Mercodia Glucagon Elisa Kit.
Antibodies. Manufacturer/supplier and catalog number for all antibodies used is provided in Supplemental Table 2. Dilutions are indicated in respective legends.

Immunohistochemistry. Immunohistochemistry was performed as previously described (72). The stained sections were observed with a BZ9000 microscope (Keyence).

Electrophysiological experiments. For the electrophysiological studies on mouse pancreatic $\beta$ cells, isolated islets were dispersed into single cells by incubation in calcium-free Hanks' solution: $137 \mathrm{mM} \mathrm{NaCl}$, $5.6 \mathrm{mM} \mathrm{KCl}, 1.2 \mathrm{mM} \mathrm{MgCl}_{2}, 1 \mathrm{mM} \mathrm{NaH} \mathrm{PO}_{4}, 10 \mathrm{mM}$ HEPES ( $\mathrm{pH} 7.4$ with $\mathrm{NaOH}$ ). For measurements of $\mathrm{K}_{\text {ATP }}$ channel currents or membrane potential, cells were maintained in RPMI media at $37^{\circ} \mathrm{C}$ in a humid atmosphere of $5 \% \mathrm{CO}_{2}$ and used the next day after isolation. $\mathrm{K}_{\text {ATP }}$ channel currents were evaluated using the standard whole-cell technique by applying a holding potential of $-70 \mathrm{mV}$ with $\pm 10 \mathrm{mV}$ steps at a duration of $250 \mathrm{~ms}$ (73). For measurement of membrane potential, islets were incubated in RPMI medium with either $5.6 \mathrm{mM}$ glucose or $25 \mathrm{mM}$ glucose at $37^{\circ} \mathrm{C}$ in a humid atmosphere of $5 \% \mathrm{CO}_{2}$ for 48 hours. Islets were then dispersed into single cells with calcium-free Hanks' solution and used after incubation for another 24 hours in RPMI media containing either $5.6 \mathrm{mM}$ glucose or $25 \mathrm{mM}$ glucose. Membrane potential measurements were performed in extracellular solution containing $1 \mathrm{mM}$ glucose. Membrane potentials were recorded in the perforated patch configuration in current-clamp mode. Perforated patch was achieved by adding pore-forming antibiotic amphotericin $B$ $(0.25 \mathrm{mg} / \mathrm{mL})$ to the pipette solution (74). Data were analyzed using Clampfit software (Molecular Devices). Electrical activity was also recorded from human $\beta$ cells in intact human pancreatic islets, as previously described (75). The $\beta$ cells were identified by functional identification based on their electrophysiological properties.

cAMP assay. Cells were plated on 96-well plates and cultured in high-glucose DMEM containing 10\% FBS. Forty-eight hours later, the media was changed to $5.6 \mathrm{mM}$ glucose DMEM containing FBS and cultured for a further 6 hours. The cells were then washed 3 times and preincubated for 30 minutes in KRBB containing $2.8 \mathrm{mM}$ glucose and then incubated for 30 minutes in indicated stimuli. To prevent cAMP degradation, the experiments were performed in the presence of 250 $\mu \mathrm{M}$ 3-isobutyl-1-methylxanthine (IBMX). Cellular cAMP content was measured by the cAMP Gs Dynamic Kit (Cisbio), according to the manufacturer's instructions.

Measurement of FRET. Seventy-two hours after transfection with the FRET sensor (a gift from Joachim Goedhart, Swammerdam Institute for Life Sciences, University of Amsterdam, Amsterdam, The Netherlands) by Effectene Transfection Reagent, the cells were subjected to imaging experiments as previously described (76). Briefly, the growth medium was replaced with KRBB containing 2.8 $\mathrm{mM}$ glucose and preincubated for 20 minutes. The cells were then observed at room temperature using confocal laser scanning microscopy (FV1000, Olympus) equipped with an UPlanSApo objective lens (100× oil/1.40 NA). The cells were excited by $440 \mathrm{~nm}$ LD laser (FV5-LDPSU, Olympus) with $0.5 \%$ output power. For kinetic FRET analysis, dual-emission imaging was performed using 2 emission filters (480DF30 for mTq2 and 535DF25 for mNG) in intervals of 5 seconds. FRET was monitored as the emission ratio of $\mathrm{mNG}$ to $\mathrm{mTq} 2$ ( $\mathrm{mNG} / \mathrm{mTq} 2$ ratio). The $\mathrm{mNG} / \mathrm{mTq} 2$ ratio was normalized to the $\mathrm{RO}$ to describe FRET efficiency changes (FRET change $=\mathrm{R} / \mathrm{RO}$ ) where RO is the $\mathrm{mNG} / \mathrm{mTq} 2$ ratio at the stimulated time point. 
Measurement of intracellular $\mathrm{Ca}^{2+}$ concentration in cell lines. Cells were loaded with $5 \mu \mathrm{M}$ fura-2 AM (Dojindo) for 20 minutes in KRBB with $2.8 \mathrm{mM}$ glucose. Intracellular $\mathrm{Ca}^{2+}$ concentration was measured by a dual-excitation wavelength method $(340 / 380 \mathrm{~nm})$ with a fluorometer (Fluoroskan Ascent CF; Labsystems) in the presence of indicated reagents. Data were expressed as the ratio of the fluorescence emission at 340/380 $\mathrm{nm}$ after background subtraction.

$\mathrm{Ca}^{2+}$ imaging analysis in human islets. Islets were preincubated for 3 days in RPMI 1640 containing either 5.5 or $16.7 \mathrm{mM}$ glucose. Before imaging, islets were loaded with $8 \mu \mathrm{M}$ Fluo-4 AM (Thermo Fisher) at room temperature $\left(21^{\circ} \mathrm{C}\right)$ for 90 minutes in imaging buffer consisting of $140 \mathrm{mM} \mathrm{NaCl}, 3.6 \mathrm{mM} \mathrm{KCl}, 0.5 \mathrm{mM} \mathrm{MgSO}_{4}, 1.3 \mathrm{mM} \mathrm{CaCl}_{2}, 10 \mathrm{mM}$ HEPES (pH 7.4 with $\mathrm{NaOH}$ ), $5 \mathrm{mM} \mathrm{NaHCO}$, and $0.5 \mathrm{mM} \mathrm{NaH}_{2} \mathrm{PO}_{4}$ with either $5.5 \mathrm{mM}$ or $16.7 \mathrm{mM}$ glucose (reflecting the culture conditions), $1 \mathrm{mg} / \mathrm{mL}$ BSA, and 0.02\% pluronic F-127 (Thermo Fisher). An islet was transferred to a poly-L-lysine-coated (MilliporeSigma) coverslip mounted in the imaging chamber (RC25, Warner Instruments) of a 2-photon microscope (TrimScope II Lavision Biotec). Before timelapse imaging, the islet was superfused for 20 minutes with imaging buffer (ES) heated to $34^{\circ} \mathrm{C}$ and containing $1 \mathrm{mM}$ glucose. The titanium-sapphire laser (MaiTai, Spectra Physics) of the microscope was tuned to $820 \mathrm{~nm}$, and images were acquired with a frame rate of $4 \mathrm{~Hz}$.

IP1 assay. Cells were plated on 384-well plates and cultured as for cAMP measurement. Following 6 hour of culture in $5.6 \mathrm{mM}$ glucose DMEM, the cells were washed 3 times and preincubated with buffer containing $146 \mathrm{mM} \mathrm{NaCl}, 4.2 \mathrm{mM} \mathrm{KCl}, 0.5 \mathrm{mM} \mathrm{MgCl}_{2}, 1.0 \mathrm{mM} \mathrm{CaCl}_{2}$, $10.0 \mathrm{mM}$ HEPES, $50 \mathrm{mM} \mathrm{LiCl}$, and $2.8 \mathrm{mM}$ glucose. The cells were then stimulated for 30 minutes in indicated stimuli. IP1 levels in the cells were measured by the IP-One HTRF Kit (Cisbio) according to the manufacturer's instructions.

RNA extraction and quantitative RT-PCR. Total RNA from mouse pancreatic islets was isolated using the QIAGEN RNA Extraction Kit per the manufacturer's instructions. From this, cDNA was prepared using the ReverTra Ace qPCR RT Kit (Toyobo) per the manufacturer's instructions. TaqMan probes (Thermo Fisher Scientific) were used to quantify relative gene expression. The reference gene used was Gap$d h$. Probe details are described in Supplemental Table 4.

RNA-Seq. Detailed methods are described in Supplemental Methods. All original and processed RNA-Seq data were deposited in the NCBI's Gene Expression Omnibus database (GEO GSE156917).

Protein assay. Cells were lysed in ice-cold buffer $(50 \mathrm{mM}$ Tris$\mathrm{HCl}, \mathrm{pH} 7.4,150 \mathrm{mM} \mathrm{NaCl}, 1 \% \mathrm{NP}-40,1 \mathrm{mM}$ EDTA, 0.1\% SDS, 0.5\% sodium deoxycholate) supplemented with protease and phosphatase inhibitor cocktails and centrifuged for 20 minutes $(13,000 g)$. Protein concentration was assessed by Pierce BCA protein assay.

Western blot analysis. Western blot analysis was performed as described previously (76) using anti-phosphoserine PKC substrates antibody (1:1000).

Statistics. Data were analyzed by GraphPad Prism, version 8.4.2, and are presented as mean \pm SEM. The significance of differences between test groups was evaluated by 2-tailed unpaired Student's $t$ test or 2-way ANOVA followed by post hoc Tukey's test or Dunnett's test. $P<0.05$ was considered statistically significant.

Study approval. All animal experiments were approved by the Committee on Animal Experimentation of Kobe University and Fukushima Medical University and carried out in accordance with the Guidelines for Animal Experimentation at the respective universities. For human islet experiments, islets were isolated in Oxford, Edmonton, and Uppsala. Islets from a total of 9 donors were used for these experiments with full approval and informed consent. Details of the donors are summarized in Supplemental Table 3.

\section{Author contributions}

S Seino conceived the project. S Seino and OSO contributed to the study design. OSO, NM, KS, HT, KM, TM, S Sakai, Y Maejima, QZ, HD, BC, CG, LK, and JT conducted in vivo, ex vivo, and in vitro experiments. HT, NY, PR, and S Seino supervised the work. OSO, HT, NY, KS, KM, QZ, HD, JT, Y Minami, PR, and S Seino were involved in data analyses and interpretation. OSO, PR, and S Seino wrote the manuscript with feedback from all other authors, including significant contributions from NM, KS, HT, NY, and TM.

\section{Acknowledgments}

We thank P.L. Hererra and J. Goedhart for providing us with RIP-Cre mice and the Gq FRET sensor, respectively. We also thank C. Carmean, T. Shibasaki, Y. Seino, T. Yada, and G. Bell for their insightful discussions. We are grateful to A. Kawabata and C. Seki for technical assistance and G. K. Honkawa for assistance in preparing the manuscript. This study was supported by Grant-in-Aid for Scientific Research from the Japan Society of the Promotion of Science, Japan to S Seino. (18H02864) and KS (17K09840). Work in the UK was supported by Diabetes UK (to QZ) and the Wellcome Trust (PR), and work in Sweden was supported by the Swedish Research council (to PR). OSO was supported by the Honjo International Scholarship Foundation, Japan, and a fellowship grant from Novo Nordisk, Denmark. NM was supported by a fellowship grant from Novo Nordisk, Denmark, and the Research Fellowship of Japan Society for the Promotion of Science Young Scientist DC1. The Department of Molecular and Metabolic Medicine is supported by MSD K.K. Novo Nordisk Pharma Ltd., Japan, Kowa Co. Ltd., and Taisho Pharmaceutical Holdings Co. Ltd.

Address correspondence to: Susumu Seino, Division of Molecular and Metabolic Medicine, Kobe University Graduate School of Medicine, 7-5-1 Kusunoki-cho, Chuo-ku, Kobe 650-0017, Japan. Email:seino@med.kobe-u.ac.jp.

TM's present address is: Department of Medical Physiology, Chiba University, Graduate School of Medicine, Chiba, Japan.
1. Henquin JC. Regulation of insulin secretion: a matter of phase control and amplitude modulation. Diabetologia. 2009;52(5):739-751.

2. Prentki M, Matschinsky FM, Madiraju SR. Metabolic signaling in fuel-induced insulin secretion. Cell Metab. 2013;18(2):162-185.
3. Wollheim CB, Sharp GW. Regulation of insulin release by calcium. Physiol Rev. 1981;61(4):914-973.

4. Seino S, Shibasaki T, Minami K. Dynamics of insulin secretion and the clinical implications for obesity and diabetes. JClin Invest. 2011;121(6):2118-2125.
5. Rorsman P, Ashcroft FM. Pancreatic $\beta$-cell electrical activity and insulin secretion: of mice and men. Physiol Rev. 2018;98(1):117-214.

6. Nichols CG. KATP channels as molecular sensors of cellular metabolism. Nature. 2006;440(7083):470-476. 
7. Seino S, Miki T. Physiological and pathophysiological roles of ATP-sensitive K+ channels. Prog Biophys Mol Biol. 2003;81(2):133-176.

8. Aguilar-Bryan L, Bryan J. Molecular biology of adenosine triphosphate-sensitive potassium channels. Endocr Rev. 1999;20(2):101-135.

9. Ahrén B. Islet $G$ protein-coupled receptors as potential targets for treatment of type 2 diabetes. Nat Rev Drug Discov. 2009;8(5):369-385.

10. Prentki M, Matschinsky FM. Ca2+, cAMP, and phospholipid-derived messengers in coupling mechanisms of insulin secretion. Physiol Rev. 1987;67(4):1185-1248.

11. Baggio LL, Drucker DJ. Biology of incretins: GLP-1 and GIP. Gastroenterology. 2007;132(6):2131-2157.

12. Yabe D, Seino Y. Two incretin hormones GLP-1 and GIP: comparison of their actions in insulin secretion and $\beta$ cell preservation. Prog Biophys Mol Biol. 2011;107(2):248-256.

13. Psichas A, Reimann F, Gribble FM. Gut chemosensing mechanisms. JClin Invest. 2015;125(3):908-917.

14. Vilsbøll T, Krarup T, Madsbad S, Holst JJ. Both GLP-1 and GIP are insulinotropic at basal and postprandial glucose levels and contribute nearly equally to the incretin effect of a meal in healthy subjects. Regul Pept. 2003;114(2-3):115-121.

15. Drucker DJ, Nauck MA. The incretin system: glucagon-like peptide-1-receptor agonists and dipeptidyl peptidases- 4 inhibitors in type 2 diabetes. Lancet. 2006;368(9548):1696-1705.

16. Elahi D, et al. The insulinotropic actions of glucose-dependent insulinotropic polypeptide (GIP) and glucagon-like peptide-1 (7-37) in normal and diabetic subjects. Regul Pept. 1994;51(1):63-74.

17. Holst JJ, Gromada J. Role of incretin hormones in the regulation of insulin secretion in diabetic and nondiabetic humans. Am J Physiol Endocrinol Metab. 2004;287(2):E199-E206.

18. Yamada Y, Miyawaki K, Tsukiyama K, Harada N, Yamada C, Seino Y. Pancreatic and extrapancreatic effects of gastric inhibitory polypeptide. Diabetes. 2006;55(suppl 2):S86-S91.

19. Nauck MA, Meier JJ. The incretin effect in healthy individuals and those with type 2 diabetes: physiology, pathophysiology, and response to therapeutic interventions. Lancet Diabetes Endocrinol. 2016;4(6):525-536.

20. Müller TD, et al. Glucagon-like peptide 1 (GLP-1). Mol Metab. 2019;30:72-130.

21. Lynn FC, Pamir N, Ng EH, McIntosh CH, Kieffer TJ, Pederson RA. Defective glucose-dependent insulinotropic polypeptide receptor expression in diabetic fatty Zucker rats. Diabetes. 2001;50(5):1004-1011.

22. Piteau S, et al. Reversal of islet GIP receptor down-regulation and resistance to GIP by reducing hyperglycemia in the Zucker rat. Biochem Biophys Res Commun. 2007;362(4):1007-1012.

23. Xu G, et al. Downregulation of GLP-1 and GIP receptor expression by hyperglycemia: possible contribution to impaired incretin effects in diabetes. Diabetes. 2007;56(6):1551-1558.

24. Younan SM, Rashed LA. Impairment of the insulinotropic effect of gastric inhibitory polypeptide (GIP) in obese and diabetic rats is related to the down-regulation of its pancreatic receptors. Gen
Physiol Biophys. 2007;26(3):181-193.

25. Inagaki N, et al. Reconstitution of IKATP: an inward rectifier subunit plus the sulfonylurea receptor. Science. 1995;270(5239):1166-1170.

26. Seino S. ATP-sensitive potassium channels: a model of heteromultimeric potassium channel/receptor assemblies. Annu Rev Physiol. 1999;61:337-362.

27. Dunne MJ, Cosgrove KE, Shepherd RM, AynsleyGreen A, Lindley KJ. Hyperinsulinism in infancy: from basic science to clinical disease. Physiol Rev 2004;84(1):239-275.

28. Ashcroft FM. ATP-sensitive potassium channelopathies: focus on insulin secretion. J Clin Invest. 2005;115(8):2047-2058.

29. Miki T, et al. Defective insulin secretion and enhanced insulin action in KATP channel-deficient mice. Proc Natl Acad Sci USA. 1998;95(18):10402-10406.

30. Minami K, et al. ATP-sensitive $\mathrm{K}^{+}$channel-mediated glucose uptake is independent of IRS-1/phosphatidylinositol 3-kinase signalling. Am JPhysiol Endocrinol Metab. 2003;285(6):E1289-E1296.

31. Miki T, et al. Distinct effects of glucosedependent insulinotropic polypeptide and glucagon-like peptide- 1 on insulin secretion and gut motility. Diabetes. 2005;54(4):1056-1063.

32. Herrera PL. Adult insulin- and glucagon-producing cells differentiate from two independent cell lineages. Development. 2000;127(11):2317-2322.

33. Seino S, et al. Glucose regulation of arginineinduced pancreatic somatostatin release from the isolated perfused rat pancreas. Regul Pept. 1982;3(3-4):271-279.

34. Braun M, et al. Somatostatin release, electrical activity, membrane currents and exocytosis in human pancreatic delta cells. Diabetologia. 2009;52(8):1566-1578.

35. Zhang Q, et al. Role of KATP channels in glucoseregulated glucagon secretion and impaired counterregulation in type 2 diabetes. Cell Metab. 2013;18(6):871-882.

36. Wheeler MB, Lu M, Dillon JS, Leng XH, Chen C, Boyd AE. Functional expression of the rat glucagon-like peptide-I receptor, evidence for coupling to both adenylyl cyclase and phospholipase-C. Endocrinology. 1993;133(1):57-62.

37. McIntosh CHS, Widenmaier S, Kim S. Glucosedependent insulinotropic polypeptide signaling in pancreatic $\beta$-cells and adipocytes. J Diabetes Investig. 2012;3(2):96-106.

38. Thorens B. Expression cloning of the pancreatic beta cell receptor for the gluco-incretin hormone glucagon-like peptide 1. Proc Natl Acad Sci US A. 1992;89(18):8641-8645.

39. Montrose-Rafizadeh C, et al. Pancreatic glucagon-like peptide-1 receptor couples to multiple $\mathrm{G}$ proteins and activates mitogen-activated protein kinase pathways in Chinese hamster ovary cells. Endocrinology.1999;140(3):1132-1140.

40. Weston C, Poyner D, Patel V, Dowell S, Ladds $\mathrm{G}$. Investigating $\mathrm{G}$ protein signalling bias at the glucagon-like peptide-1 receptor in yeast. $\mathrm{Br} J$ Pharmacol. 2014;171(15):3651-3665.

41. Shigeto M, et al. GLP-1 stimulates insulin secretion by PKC-dependent TRPM4 and TRPM5 activation. J Clin Invest. 2015;125(12):4714-4728.

42. Nishimura A, et al. Structural basis for the spe- cific inhibition of heterotrimeric Gq protein by a small molecule. Proc Natl Acad Sci U S A. 2010;107(31):13666-13671.

43. Gautam D, et al. A critical role for beta cell M3 muscarinic acethylcholine receptors in regulating insulin release and blood glucose homeostasis in vivo. Cell Metab. 2006;3(6):449-461.

44. Miller C, et al. GPR40 partial agonist MK-2305 lower fasting glucose in the Goto Kakizaki rat via suppression of endogenous glucose production. PLOS ONE. 2017;12(5):e0176182.

45. Murao N, et al. Essential roles of aspartate aminotransferase 1 and vesicular glutamate transporters in $\beta$-cell glutamate signaling for incretin-induced insulin secretion. PLOS ONE. 2017;12(11):e0187213.

46. Rasmussen $\mathrm{H}$, et al. Diacylglycerol production, $\mathrm{Ca}^{2+}$ influx, and protein kinace $\mathrm{C}$ activation in sustained cellular responses. Endocr Rev. 1995;16(5):649-681.

47. Wess J. Molecular basis of receptor/G-protein-coupling selectivity. Pharmacol Ther. 1998;80(12):231-264.

48. He Q, et al. A G protein-coupled, IP3/protein kinase $\mathrm{C}$ pathway controlling the synthesis of phosphaturic hormone FGF23. JCI Insight. 2019;4(17):e125007.

49. Mastop M, Bindels DS, Shaner NC, Postma M, Gadella TWJ, Goedhart J. Characterization of a spectrally diverse set of fluorescent proteins as FRET acceptors for mTurquoise2. Sci Rep. 2017;7(1):11999.

50. Mahaut-Smith MP, Martinez-Pinna J, Gurung IS. A role for membrane potential in regulating GPCRs? Trends Pharmacol Sci. 2008;29(8):421-429.

51. Shyr ZA, Wang Z, York NW, Nichols CG, Remedi MS. The role of membrane excitability in pancreatic $\beta$-cell glucotoxicity. Sci Rep. 2019;9(1):6952.

52. Tomino Y. Lessons from the KK-Ay mouse, a spontaneous animal model for the treatment of human type 2 diabetic nephropathy. Nephro-Urol Mon. 2012;4(3):524-529.

53. Hamilton A, et al. Adrenaline stimulates glucagon secretion by Tpc2-dependent $\mathrm{Ca}^{2+}$ mobilization from acidic stores in pancreatic $\alpha$-cells. Diabetes. 2018;67(6):1128-1139.

54. Katritch V, Fenalti G, Abola EE, Roth BL, Cherezon V, Stevens RC. Allosteric sodium in class A GPCR signalling. Trends Biochem Sci. 2014;39(5):233-244.

55. Vickery ON, Machtens JP, Zachariae U. Membrane potentials regulating GPCRs: insights from experiments and molecular dynamics simulations. Curr Opin Pharmacol. 2016;30:44-50.

56. Shalaeva DN, Cherepanov DA, Galperin MY, Vriend G, Mulkidjanian AY. G protein-coupled receptors of class A harness the energy of membrane potential to increase their sensitivity and selectivity. Biochim Biophys Acta Biomembr. 2019;1861(12):183051.

57. Fenalti $G$, et al. Molecular control of $\delta$-opioid receptor signalling. Nature. 2014;506(7487):191-196.

58. Wooten D, Miller LJ. Structural basis for allosteric modulation of class B $\mathrm{G}$ protein-coupled receptors. Annu Rev Pharmacol Toxicol. 2020;60:89-107.

59. Selvam B, Shamsi Z, Shukla D. Universality of the sodium ion binding mechanism in class A G-protein-coupled receptors. Angew Chem Int Ed Engl. 
2018;57(12):3048-3053.

60. Hollenstein K, de Graat C, Bortolato A, Wang $\mathrm{M}-\mathrm{W}$, Marshall FH, Stevens RC. Insights into the structure of class B GPCRs. Trends Pharmacol Sci. 2014;35(1):12-22.

61. Ben-Chaim Y, Tour O, Dascal N, Parnas I, Parnas H. The M2 muscarinic G-proteincoupled receptor is votage-sensitive. J Biol Chem. 2003;278(25):22482-22491.

62. Thore S, Dyachok O, Tengholm A. Oscillations of phospholipase $\mathrm{C}$ activity triggered by depolarization and $\mathrm{Ca} 2+$ influx in insulin-secreting cells. J Biol Chem. 2004;279(19):19396-19400.

63. Kashima Y, et al. Critical role of cAMP-GEFII-Rim2 complex in incretin-potentiated insulin secretion. JBiol Chem. 2001;276(49):46046-46053.

64. Seino S, Shibasaki T. PKA-dependent and PKA-independent pathways for cAMP-regulated exocytosis. Physiol Rev. 2005;85(4):1303-1342.

65. Bonev AD, Nelson MT. Muscarinic inhibition of ATP-sensitive $\mathrm{K}+$ channels by protein kinase $\mathrm{C}$ in urinary bladder smooth muscle. Am JPhysiol. 1993;265(6 Pt 1):C1723-C1728.
66. Taylor R. Calorie restriction and reversal of type 2 diabetes. Expert Rev Endocrinol Metab. 2016;11(6):521-528.

67. Højberg PV, et al. Four weeks of near-normalisation of blood glucose improves the insulin response to glucagon-like peptide- 1 and glucose-dependent insulinotropic polypeptide in patients with type 2 diabetes. Diabetologia. 2009;52(2):199-207.

68. Ahn HC, Oh JT, Kwak HS, Cho YM. Sodiumglucose cotranspoter-2 inhibition improves incretin sensitivity of pancreatic $\beta$-cells in people with type 2 diabetes. Diabetes Obes Metab. 2018;20(2):370-377.

69. Iwasaki M, Minami K, Shibasaki T, Miki T, Miyazaki J, Seino S. Establishment of new clonal pancreatic $\beta$-cell lines (MIN6-K) useful for study of incretin/cyclic adenosine monophosphate signalling. J Diabetes Investig. 2010;1(4):137-142.

70. Wollheim C, Meda P, Halban PA. Isolation of pancreatic islets and primary culture of intact microorgans or of dispersed islet cells. Methods Enzymol.1990;192:188-223.
71. Takahashi H, et al. Role of Epac2A/Rap1 signaling in interplay between incretin and sulfonylurea in insulin secretion. Diabetes. 2015;64(4):1262-1272.

72. Tamura K, Minami K, Kudo M, Iemoto K, Takahashi H, Seino S. Liraglutide improves pancreatic Beta cell mass and function in alloxan-induced diabetic mice. PLoS ONE. 2015;10(5):e0126003.

73. Girard CA, et al. Expression of an activating mutation in the gene encoding the KATP channel subunit Kir6.2 in mouse pancreatic beta cells recapitulates neonatal diabetes. JClin Invest. 2009;119(1):80-90.

74. Maejima Y, et al. Nesfatin-1 inhibits voltage gated $\mathrm{K}^{+}$channels in pancreatic beta cells. Peptides. 2017;95:10-15.

75. Braun M, et al. Voltage-gated ion channels in human pancreatic beta-cells: electrophysiological characterization and role in insulin secretion. Diabetes. 2008;57(6):1618-1628.

76. Zhang CL, et al. The cAMP sensor Epac2 is a direct target of antidiabetic sulfonylurea drugs. Science. 2009;325(5940):607-610. 